\title{
The short- and long-term proteomic effects of sleep deprivation on the cortical and thalamic synapses
}

\author{
Attila Simor ${ }^{\mathrm{a}}$, Balázs András Györffy ${ }^{\mathrm{a}, \mathrm{b}}$, Péter Gulyássy ${ }^{\mathrm{a}, \mathrm{c}}$, Katalin Völgyi ${ }^{\mathrm{a}, \mathrm{d}}$, Vilmos Tóth ${ }^{\mathrm{a}, \mathrm{c}}$, \\ Mihail Ivilinov Todorov ${ }^{\mathrm{a}}$, Viktor Kis ${ }^{\mathrm{e}}$, Zsolt Borhegyi ${ }^{\mathrm{f}}$, Zoltán Szabó ${ }^{\mathrm{g}}$, Tamás Janáky ${ }^{\mathrm{g}}$, László Drahos ${ }^{\mathrm{c}}$, \\ Gábor Juhász $^{\text {a,c }}$, Katalin Adrienna Kékesi a,h,* \\ a Laboratory of Proteomics, Institute of Biology, Eötvös Loránd University, Budapest H-1117, Hungary \\ ${ }^{\mathrm{b}}$ MTA-ELTE NAP B Neuroimmunology Research Group, Department of Biochemistry, Institute of Biology, Eötvös Loránd University, Budapest H-1117, Hungary \\ c MTA-TTK NAP B MS Neuroproteomics Research Group, Hungarian Academy of Sciences, Budapest H-1117, Hungary \\ d MTA-ELTE NAP B Laboratory of Molecular and Systems Neurobiology, Institute of Biology, Hungarian Academy of Sciences and Eötvös Loránd University, Budapest H-1117, Hungary \\ e Department of Anatomy, Cell and Developmental Biology, Institute of Biology, Eötvös Loránd University, Budapest H-1117, Hungary \\ ${ }^{\mathrm{f}}$ MTA-ELTE-NAP B Opto-Neuropharmacology Group, Hungarian Academy of Sciences and Eötvös Loránd University, Budapest H-1117, Hungary \\ ${ }^{g}$ Institute of Medical Chemistry, University of Szeged, Szeged H-6720, Hungary \\ h Department of Physiology and Neurobiology, Eötvös Loránd University, Budapest H-1117, Hungary
}

\section{A R T I C L E I N F O}

\section{Article history:}

Received 2 June 2016

Revised 7 December 2016

Accepted 6 January 2017

Available online 10 January 2017

\section{Keywords:}

Sleep deprivation

Parietal cortex

Thalamus

Synaptosome

2D-DIGE proteomics

Synaptic homeostasis hypothesis

\begin{abstract}
A B S T R A C T
Acute total sleep deprivation (SD) impairs memory consolidation, attention, working memory and perception. Structural, electrophysiological and molecular experimental approaches provided evidences for the involvement of sleep in synaptic functions. Despite the wide scientific interest on the effects of sleep on the synapse, there is a lack of systematic investigation of sleep-related changes in the synaptic proteome. We isolated parietal cortical and thalamic synaptosomes of rats after $8 \mathrm{~h}$ of total SD by gentle handling and $16 \mathrm{~h}$ after the end of deprivation to investigate the short- and longer-term effects of SD on the synaptic proteome, respectively. The SD efficiency was verified by electrophysiology. Protein abundance alterations of the synaptosomes were analyzed by fluorescent two-dimensional differential gel electrophoresis and by tandem mass spectrometry. As several altered proteins were found to be involved in synaptic strength regulation, our data can support the synaptic homeostasis hypothesis function of sleep and highlight the long-term influence of SD after the recovery sleep period, mostly on cortical synapses. Furthermore, the large-scale and brain area-specific protein network change in the synapses may support both ideas of sleep-related synaptogenesis and molecular maintenance and reorganization in normal rat brain.
\end{abstract}

(c) 2017 Elsevier Inc. All rights reserved.

\section{Introduction}

The idea that sleep contributes to maintain normal brain functions as memory formation and behavior has been developed several decades ago (Bloch et al., 1977, 1979; Blissitt, 2001; Dang-Vu et al., 2006). It is supported by the facts that the majority of brain disorders are accompanied by sleep disturbances (Reynolds et al., 1988; Vitiello et al., 1990, 1991; Starkstein et al., 1991; Wiegand et al., 1991; Donnet et al., 1992;

Abbreviations: 2D-DIGE, two-dimensional differential gel electrophoresis; EEG, electroencephalogram; EMG, electromyogram; FFT, Fast Fourier transform; MS/MS, tandem mass spectrometry; LTP, long-term potentiation; RS, recovery sleep; RS, experiment 2: the brains of rats were removed $16 \mathrm{~h}$ after the end of deprivation; SD, sleep deprivation; SD, experiment 1: the brains of rats were removed after $8 \mathrm{~h}$ of total sleep deprivation performed by gentle handling.

* Corresponding author at: Laboratory of Proteomics, Institute of Biology, Eötvös Loránd University, Pázmány Péter sétány 1/C, Budapest H-1117, Hungary.

E-mail address: kakekesi@ttk.elte.hu (K.A. Kékesi).
Baker and Richdale, 2015; Murphy and Peterson, 2015) and sleep deprivation causes memory impairment (Youngblood et al., 1997; Ishikawa et al., 2006), perception (Goel et al., 2005; Lei et al., 2015) and mood (Short and Louca, 2015) deficits.

Recently, two dominant ideas are formed concerning the general function of sleep, focusing mainly on the synapses. The synaptic homeostasis hypothesis (Tononi and Cirelli, 2003, 2006) suggests that sleep is necessary to decrease the enhanced synaptic strength that gradually develops during wakefulness to maintain the optimal balance between flexibility and rigidity in synapses which is crucial for normal brain function. This hypothesis predicted and partly proved the weakening of synaptic connection strength during sleep particularly in the cerebral cortex (Watson and Buzsáki, 2015). The synaptic homeostasis hypothesis emphasizes that the continuous molecular adjustment of the synapses during the active period makes them rigid through a "saturation" of the synaptic strength, therefore, decreases the ability of learning novel information. Thus, sleep reduces synaptic strength in general (Tononi 
and Cirelli, 2014). Another theory assumes the formation of novel dendritic spines, and in turn, synapses during slow-wave sleep, suggesting long-term memory inscription via development of novel synapses during sleep (Yang et al., 2014). The hypothesis of enhanced synaptogenesis during sleep points out that long-term memory trace consolidation is an important function of sleep and it is based on the genesis of novel dendritic spines and synapses (Matsuzaki et al., 2004) to change the neuronal connectome (Chow et al., 2013; Picchioni et al., 2013). While the synaptic homeostasis theory attempts to explain the restoration of "printability" of synapses, the intensive learning-induced, sleepdependent synaptogenesis hypothesis suggests a mechanism which underlies the consolidation of long-term memory traces into the neuronal connectome. Both ideas are based on the fact that long-term memory traces require the ability of generating novel synapses and fundamental maintenance of flexibility in the protein composition of existing synapses (Trachtenberg et al., 2002; Klann and Sweatt, 2008).

Synaptogenesis and adjustment of synaptic strength are the results of molecular changes in synapses due to de novo protein synthesis (Martin et al., 2000) and/or incorporation of trafficking proteins into the synapse (Rumpel et al., 2005) during the memory consolidation process. As a model of synaptic plasticity induced by strong stimuli, long-term potentiation (LTP) is a good tool for studying molecular changes in synapses (Abraham and Otani, 1991; Sweatt, 1999). A fast imprinting into the synapse mediated by e.g., short-term kinase activity and protein trafficking is the major mechanism of early-phase LTP, lasting from a few seconds up to several hours after stimulation onset (Huang, 1998). The synaptogenesis and synaptic size increase were shown in the late phase of LTP (Tominaga-Yoshino et al., 2008). Most importantly, LTP is affected by sleep and sleep deprivation (McDermott et al., 2003; Blanco et al., 2015). These results further strengthen the idea that some sort of molecular maintenance and reorganization in synapses in conjunction with memory consolidation and recovery of learning capabilities are major functions of sleep.

There are several molecular changes in sleep and sleep deprivation uncovered by measuring mRNA level changes (Cirelli and Tononi, 1998; Cirelli et al., 2006; Terao et al., 2003a, 2003b; Mackiewicz et al., 2007; Jones et al., 2008; Vecsey et al., 2012) and also some protein level alterations have been revealed (Basheer et al., 2005; Pawlyk et al., 2007; Poirrier et al., 2008). However, focused high-throughput examination of the synaptic proteome is still lacking. The synaptic proteome contains more than 1,000 known proteins, but this number can be higher, since the available literature provides very different numbers of synaptic proteins probably due to the methodological heterogeneity in the field of proteomics (see http://www.synprot.de) (Pielot et al., 2012). Moreover, the majority of the synaptic proteins are also crucial in other cellular compartments of the neurons. Synapses are supplied by proteins from the local protein synthesis (Martin et al., 2000) and also by selection of proteins from axonal and dendritic protein trafficking systems (Vallee and Bloom, 1991). Interestingly, a general increase in the brain tissue protein synthesis has been revealed during sleep (Ramm and Smith, 1990; Nakanishi et al., 1997) but the data are not specific for the synaptic proteome.

The changes specific to the synaptic protein network underlying the sleep-related adjustment of synaptic strength are poorly understood. In this study, we performed a parietal cortical and thalamic synaptosome proteomic study of rats. The parietal cortex receives inputs from the thalamus which is necessary for genesis of synchronous sleep-related activity in the cortex as extensively studied by Steriade and others (for review, see Steriade and Llinás, 1988). It is also known that the detrimental effects of sleep deprivation are particularly pronounced in the thalamus and parietal cortex (among other cortical structures) (Chee and Choo, 2004; Chee et al., 2006). Therefore, the proteomics study was conducted on samples of thalamo-cortical cross-linked areas of the brain highly sensitive to sleep deprivation. Surprisingly, sleep deprivation inversely affects the activation-state of thalamus and the parietal cortex (Tomasi et al., 2009), emphasizing the importance of separately assessing molecular changes in these brain areas. The proteomic changes were characterized in both brain areas after $8 \mathrm{~h}$ of total sleep deprivation (SD) and $16 \mathrm{~h}$ after the end of deprivation, when recovery sleep (RS) of sleep deprived animals took place. This experimental design enabled monitoring the effects of SD and RS on the synaptic proteome in relevant brain areas.

\section{Materials and methods}

\subsection{Animals}

Adult male Sprague-Dawley rats (4 months old, weighing 350$400 \mathrm{~g}$; Charles River Laboratories, Hungary) were used ( $n=24$ for proteomic experiment, $n=6$ for electron microscopy and sleep deprivation validation). Animals were housed under standard laboratory conditions (lights on at 9:00 AM, lights off at 9:00 PM), with free access to water and food. The care and treatment of all animals were in conform to Council Directive 86/609/EEC, the Hungarian Act of Animal Care and Experimentation (1998, XXVIII), and local regulations for the care and use of animals in research. All efforts were taken to minimize the animals' pain and suffering and to reduce the number of animals used.

\subsection{Experimental paradigm}

Sleep deprivation started at 9:00 AM (lights on) and lasted $8 \mathrm{~h}$ long until 5:00 PM. In the SD experiment, brains of sleep deprived $(n=6)$ and control $(n=6)$ rats were removed right after the ending of the deprivation. In the RS experiment, brains of sleep deprived $(n=6)$ and undisturbed, control $(n=6)$ rats were removed $16 \mathrm{~h}$ after finishing the deprivation, at 9:00 AM, on the next day. For the experimental paradigm, see Fig. 1.

\subsection{Sleep deprivation procedure and estimation of its effectivity by EEG and EMG}

Sleep deprivation was carried out using the gentle handling method which is the least stressful method of total sleep deprivation (Ledoux et al., 1996; Rechtschaffen et al., 1999; Fenzl et al., 2007).

For electroencephalogram (EEG) recordings, rats were implanted with stainless steel screw electrodes $(0.8 \mathrm{~mm}$ o.d.) and with teflon-coated, stainless steel multiwire muscle electrodes for electromyogram (EMG) recordings. Animals were anesthetized with $1 \%(\mathrm{v} / \mathrm{v})$ isoflurane. The screw electrodes were implanted into the skull, bilaterally above the occipital, parietal and frontal cortices. Ground and reference electrodes were placed above the cerebellar cortex. The electrodes were fixed on the skull using dentacrylate cement, and were soldered to ten-pin sockets. Sleep deprivation and polygraphic recordings were performed after one week recovery period.

EEG and EMG were recorded by a Grass Model 8B (Grass Instrument Company) electroencephalograph attached to a CED 1401 mkII data capture and analysis device, using Spike 2 software (Cambridge Electronic Design Limited). The bandwidth of the EEG recording was $0.5-70 \mathrm{~Hz}$ and $5-300 \mathrm{~Hz}$ for the EMG recording. Signals were digitalized at $500 \mathrm{~Hz}$ sampling rate for EEG and at $900 \mathrm{~Hz}$ for EMG. Power density analysis was performed using Fast Fourier transform (FFT size 8192, Hanning window) in Spike 2. Somnograms were produced by sleep scoring that was made in $30 \mathrm{~s}$ epochs by a script provided by Cambridge Electronic Design Limited for the Spike 2 software ("RatSleepAuto" script; Costa-Miserachs et al., 2003).

\subsection{Synaptosome preparation}

Synaptosome isolation was performed immediately after the brain removal. Quickly removed brains were placed into ice-cold artificial cerebrospinal fluid and brain structures were dissected on a dry ice-cooled plate. Subsequently, parietal cortices and thalami were removed. From 


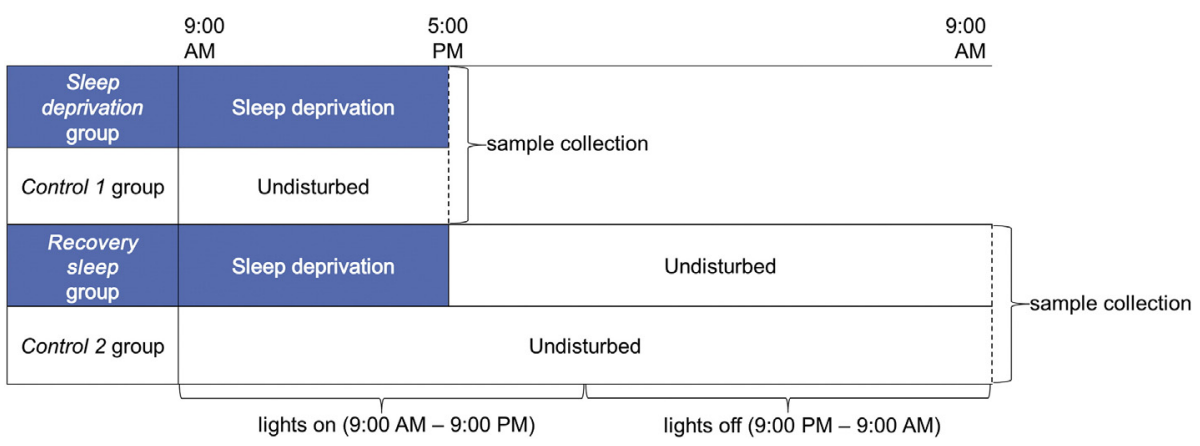

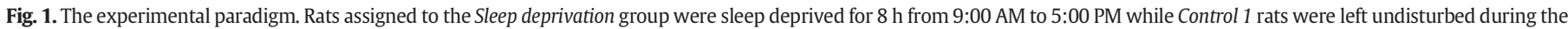

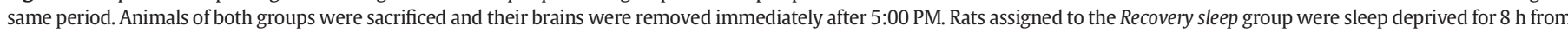

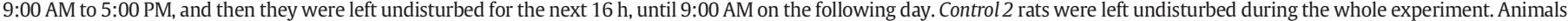
of the latter two groups were sacrificed at 9:00 AM on the next day.

the cerebral cortices, cortical white matter was separated and the gray matter was further processed.

Synaptosome fractionation was carried out strictly following the protocol published by Bajor et al. (2012). In brief, brain samples were placed into homogenization buffer ( $320 \mathrm{mM}$ sucrose, $5 \mathrm{mM}$ HEPES, $1 \mathrm{mM} \mathrm{MgCl}$, $\mathrm{pH}$ 7.4) supplemented with protease and phosphatase inhibitor cocktails (Sigma-Aldrich) and homogenized with a Dounce Tissue Grinder manually (40 strokes per sample; Sigma-Aldrich) at $4{ }^{\circ} \mathrm{C}$ with pre-cooled equipment. After homogenization, samples were centrifuged at $4{ }^{\circ} \mathrm{C}$ with $1000 \times \mathrm{g}$ for $10 \mathrm{~min}$, the supernatant was gravity filtered through a $5 \mu \mathrm{m}$ pore-size PVDF membrane (Merck Millipore) and centrifuged at $4{ }^{\circ} \mathrm{C}$ with $12,000 \times g$ for $30 \mathrm{~min}$. The pelleted synaptosomes purified for electron microscopy examinations were immediately processed as described in Section 2.5, while proteins of the samples obtained for the proteomics study were precipitated with acetone overnight at $-20^{\circ} \mathrm{C}$. The protein pellet was resuspended in lysis buffer ( $7 \mathrm{M}$ urea, $2 \mathrm{M}$ thiourea, 4\% (w/v) CHAPS, $20 \mathrm{mM}$ Tris, $5 \mathrm{mM}$ magnesium-acetate) and stored at $-80{ }^{\circ} \mathrm{C}$.

\subsection{Electron microscopy}

The synaptosome samples were fixed in $2 \%$ formaldehyde (freshly depolymerized from paraformaldehyde), $1 \%$ glutaraldehyde in $0.1 \mathrm{M}$ sodium cacodylate buffer, $\mathrm{pH} 7.4$ for $30 \mathrm{~min}$ at room temperature (RT). After extensive washing, samples were postfixed in $0.25 \%$ osmium tetroxide, $0.4 \%$ potassium hexacyanoferrate for $60 \mathrm{~min}$, and en bloc stained with aqueous uranyl acetate for $30 \mathrm{~min}$. Subseqently, synaptosome samples were dehydrated and embedded in LR White resin (Sigma-Aldrich) according to the manufacturer's instructions. Ultrathin sections $(70 \mathrm{~nm}$ ) were collected on 400 mesh copper grids (Sigma-Aldrich) and stained with half saturated aqueous uranyl acetate for $10 \mathrm{~min}$, and lead citrate for $30 \mathrm{~s}$. The grids were examined with a JEM-1011 electron microscope (JEOL) operating at $60 \mathrm{kV}$. Images were acquired and processed with an 11 megapixel Olympus Morada camera with iTEM software (Olympus Corporation). The images were taken from different mesh along a longitudinal band to cover the entire width of the specimen.

\subsection{Two-dimensional differential in-gel electrophoresis (2D-DIGE)}

In the proteomics experiment, we compared SD with Control1 and RS with Control 2 cortical and thalamic groups separately (4 independent experiments were conducted). The applied protocol was described previously by Szegő et al. (2010). Briefly, pH of the samples was adjusted to 8.5 and the protein concentration was determined. Samples of $50 \mu \mathrm{g}$ protein content were labeled with CyDye DIGE Fluor Minimal Labeling Kit, according to the manufacturer's instructions (GE Healthcare).
Control and sleep deprivation samples were labeled with Cy3 and Cy5 randomly, and a pooled sample, serving as internal standard, was labeled with Cy2. After mixing the labeled samples, isoelectric focusing buffer was added, and the dry strips were rehydrated overnight at room temperature. Isoelectric focusing was performed for $24 \mathrm{~h}$ to attain a total of $80 \mathrm{kVh}$. After isoelectric focusing, the proteins were reduced and carbamidomethylated in equilibrating buffer and the strips were placed onto the top of $10 \%$ polyacrylamide gels $(24 \times 20 \mathrm{~cm})$ casted in the laboratory. Running was conducted using an Ettan DALT System (GE Healthcare) at $2 \mathrm{~W} /$ gel for $1 \mathrm{~h}$ and at $12 \mathrm{~W} /$ gel for $3 \mathrm{~h}$. Finally, gels were scanned with a TyphoonTRIO + scanner (GE Healthcare) and analyzed with DeCyder 2D 7.0 software package (GE Healthcare). Protein spots with significant difference between control and sleep deprivation samples (independent Student's $t$-test, $p<0.05$ ) and with higher than \pm 1 .1-fold changes were selected. For protein identification, a preparative gel containing $800 \mu \mathrm{g}$ protein was run and stained with Colloidal Coomassie Blue G-250 (Merck Millipore). The spots of interest were manually excised from the preparative gel and stored in $0.5 \%(\mathrm{v} / \mathrm{v})$ acetic acid solution until the mass spectrometry analysis.

\subsection{Protein identification by mass spectrometry and functional classification}

Proteins from the excised spots were digested with trypsin using the in-gel digestion protocol without reduction and alkylation of cysteins, as described previously (Szabó et al., 2012). Digested protein samples were analyzed on a Waters NanoAcquity UPLC system coupled with a Micromass Q-TOF premier mass spectrometer (Waters Corporation). Five $\mu \mathrm{L}$ of samples were full-loop injected, and initially transferred with an A eluent to the precolumn at a flow rate of $10 \mu \mathrm{L} / \mathrm{min}$ for $1 \mathrm{~min}$. The column was eluted with a linear gradient of 3-10\% B over 0-1 min, 10-30\% B over 1-20 min, 30-100\% B over 20-21 min, the composition was maintained $100 \% \mathrm{~B}$ for $1 \mathrm{~min}$ and then returned to $3 \%$ for $1 \mathrm{~min}$. The column was re-equilibrated at initial conditions for $22 \mathrm{~min}$. Mobile phase A was $0.1 \%$ formic acid in water, while mobile phase B was $0.1 \%$ formic acid in acetonitrile. A $350 \mathrm{~nL} / \mathrm{min}$ flow rate was applied on a Waters BEH130 C18 $75 \mu \mathrm{m} \times 150 \mathrm{~mm}$ column with $1.7 \mu \mathrm{m}$ particle size C18 packing (Waters Corporation). The column was thermostated at $45{ }^{\circ} \mathrm{C}$. The mass spectrometer was operated in DDA mode with lockmass correction, with a nominal mass accuracy of $3 \mathrm{ppm}$. The instrument was operated in positive ion mode, performing full-scan analysis over the $m / z$ range $400-1990$ at $1 / 1$ spectra/s for MS and $50-1990$ in MS/MS. The source temperature was set at $85^{\circ} \mathrm{C}$ and nitrogen was used as the desolvation gas ( 0.5 bar). Capillary voltage and cone voltage were maintained at $3.3 \mathrm{kV}$ and $26 \mathrm{~V}$, respectively.

All acquired data were processed by the WATERS Proteinlynx GlobalServer 2.4 software (Waters Corporation) using default settings. 
Database search was performed using Mascot 2.204 (Matrix Science) which was set up to search the latest Swissprot database assuming the digestion enzyme trypsin, allowing 2 missed cleavage sites. The data were searched with 0.15 Da fragment and $60 \mathrm{ppm}$ parent ion mass tolerances. Oxidation of methionine was specified as a variable, and carbamidomethylation of cysteine as a fixed amino acid modification.

Scaffold v 3.09 (Proteome Software) was used to validate MS/MS based peptide and protein identifications. Peptide and protein identifications were accepted if they could be established at greater than $95.0 \%$ probability and proteins contained at least 2 identified peptides. Protein probabilities were assigned by the Protein Prophet algorithm. Proteins that contained similar peptides and could not be differentiated based on MS/MS analysis alone were grouped to satisfy the principles of parsimony, in these cases representatives of grouped accession numbers are listed.

Functional classification of the proteins was carried out via thorough literature mining and using the UniProt protein database (http://www. uniprot.org).

\subsection{Western blot}

Western blot experiments were conducted to validate the synaptosome preparation protocol and our proteomics results. First, protein concentration of samples was determined with 2-D Quant Kit (GE Healthcare). Samples containing equal amounts of proteins were mixed with two-fold concentrated sample buffer ( $8 \%$ (wt/vol) sodium dodecyl sulfate, 3\% (wt/vol) dithiothreitol, 24\% (vol/vol) glycerol, $0.2 \%$ (wt/vol) bromophenol blue, $100 \mathrm{mM}$ Tris- $\mathrm{HCl}$ ( $\mathrm{pH} \mathrm{6.8)}$ ) and protein separation was conducted in $10 \%$ polyacrylamide gels using TricineSDS discontinuous polyacrylamide gel electrophoresis. Subsequently, proteins were transferred onto Hybond-LFP PVDF membranes (GE Healthcare). After blocking of the blots with Tris-buffered saline containing $5 \%$ bovine serum albumin, $0.05 \%$ Tween-20 for $1 \mathrm{~h}$, membranes were incubated overnight in the blocking buffer with the appropriate primary antibody. For antibody against a well-characterized synaptic marker, we used anti-Psd95 primary antibody (1:1,500 dilution, Thermo Fisher Scientific, catalog number: MA1-046), while anti-Actin antibody (1:1,000 dilution, Abcam, catalog number: ab1801) was used to detect levels of actin as loading control. In order to validate our proteomics data, we used primary antibodies against altered proteins, as follows: anti-Anxa3 (1:800 dilution, Thermo Fisher Scientific, catalog number: PA5-41314), anti-Crmp2 (also known as Dpysl2) (1:5,000 dilution, Abcam, catalog number: ab62661), and anti-Hspa8 (1:500 dilution, Merck Millipore, catalog number: MABE1120). After washing steps, membranes were incubated with appropriate secondary antibodies, as follows: ECL Plex Goat- $\alpha$-mouse IgG Cy3-and Cy5 (both of them in $1: 2,500$ dilution; GE Healthcare). Finally, proteins of interest were detected using a TyphoonTRIO + scanner, while the densitometric analyses were performed with the ImageJ image processing program (http://imagej.nih.gov/ij/; Abramoff et al., 2004). Densitometric data of Psd95 protein was normalized to the level of actin. In the course of the densitometric evaluation of Anxa3, Dpysl2, and Hspa8 levels, we used densitometric data normalized to the densities of the total protein amounts of the appropriate lanes using Coomassie Brilliant Blue R-250 (Merck Millipore) staining (according to Eaton et al., 2013). This method was employed because we observed alterations in the level of protein spots of actin in most of our experiments. Statistical analyses were evaluated using independent Student's $t$-test.

\section{Results}

3.1. Characterization of the sleep deprivation procedure and the synaptosome fraction

In order to test the applied sleep deprivation method, EEG and EMG recordings were carried out on a group of animals. Somnograms, representative EEG and EMG recordings, complemented with the FFT analysis results of the corresponding EEG data from undisturbed, control, and sleep deprived rats, moreover, from rats during the recovery sleep period are shown in Fig. 2. Sleep deprivation procedure was performed with the gentle handling method that kept the rats awake almost entirely during the $8 \mathrm{~h}$ long recording, since the sleep deprived rats were awake in $97.3 \pm 1.2 \%$ of the recorded period (mean \pm standard deviation, $n=6$ ). Analyzing the polygraphic record of sleep in the different experimental sessions in details also demonstrated that the efficiency of sleep deprivation was appropriate, since very few if any delta activity was recorded in the sleep deprivation group (Fig. 2, middle panels). Sleep deprived rats were mostly characterized by high power of theta frequency. On the other hand, the recovery sleep period after the sleep deprivation procedure was characterized by more slowwave sleep activity (Fig. 2, bottom panels) than that of the control animals (Fig. 2, upper panels), and an increased delta power was found in their power spectra. Altogether, our physiological data confirmed that the applied sleep deprivation method was efficient and recovery sleep was observed.

Our proteomics study was conducted on a synaptosome fraction, the purity of which was accurately validated. First, Western blot analyses demonstrated the prominent enrichment of the synaptic marker protein Psd95 in the synaptosome fraction prepared from the cerebral cortex in comparison with the whole cortical homogenate (Fig. 3A). Moreover, electron micrographs showed intact synaptosomes, as sealed, synaptic vesicle-filled presynaptic terminals and tightly attached postsynaptic compartments were present (Fig. 3B).

\subsection{Widespread proteomic alterations characterize the parietal cortical and thalamic synapses due to sleep deprivation}

Gel-based proteomic tools were used to investigate the sleep deprivation-induced short- and longer-term changes in the synaptic proteome of parietal cortices and thalami of rats. A total of $\sim 1600-1700$ proteins were detected on every single gel. Thirty-two statistically significantly altered spots were detected in the SD experiment from the parietal cortex, and 7 from the thalamus, while the RS experiment revealed 126 and 34 changed spots in the parietal cortex and thalamus, respectively (Figs. 4 and 5; Suppl. Tables 1-4). One hundred and forty-two different proteins were identified altogether with significantly changed amounts in the SD and RS experiments from the cortical and thalamic samples. The SD experiment revealed 53 altered proteins from the parietal cortex and 19 from the thalamus, while the RS experiment showed 95 proteins from the parietal cortex with changed abundances and 28 from the thalamus (see Tables 1-4 and Suppl. Tables 1-4). The fold changes of the altered spots were in the ranges of -1.1 up to -1.71 and 1.1-1.59 (Fig. 6A-D). From the 125 different cortical proteins, 24 were found to be influenced by both the short- and long-term effects of sleep deprivation, while from the 45 thalamic proteins, 2 overlapping in the SD and RS experiment were observed.

The identified proteins were clustered according to their cellular functions and assigned to cellular localizations, based on the rigorous analysis of the literature and using the UniProt protein database (see Tables 1-4 and Fig. 6E-H). The affected cellular functions were as follows: carbohydrate and energy metabolism (SD cortex: 17 proteins, SD thalamus: 2, RS cortex: 26 , RS thalamus: 7 ), amino acid metabolism (SD cortex: 3 proteins, SD thalamus: 1, RS cortex: 2, RS thalamus: 1 ), lipid metabolism (SD cortex: 1 protein, SD thalamus: 0 , RS cortex: 1 , RS thalamus: 1 ), nucleotide metabolism (SD cortex: 2 proteins, SD thalamus: 1, RS cortex: 1, RS thalamus: 0 ), synaptic transmission (SD cortex: 5 proteins, SD thalamus: 3, RS cortex: 9, RS thalamus: 4), protein synthesis and folding (SD cortex: 10 proteins, SD thalamus: 7, RS cortex: 11, RS thalamus: 4), proteolysis (SD cortex: 0 protein, SD thalamus: 2 , RS cortex: 2, RS thalamus: 2), response to oxidative stress (SD cortex: 1 protein, SD thalamus: 0 , RS cortex: 9 , RS thalamus: 2 ), cytoskeletal (SD cortex: 8 proteins, SD thalamus: 3 , RS cortex: 14 , RS thalamus: 2 ), 


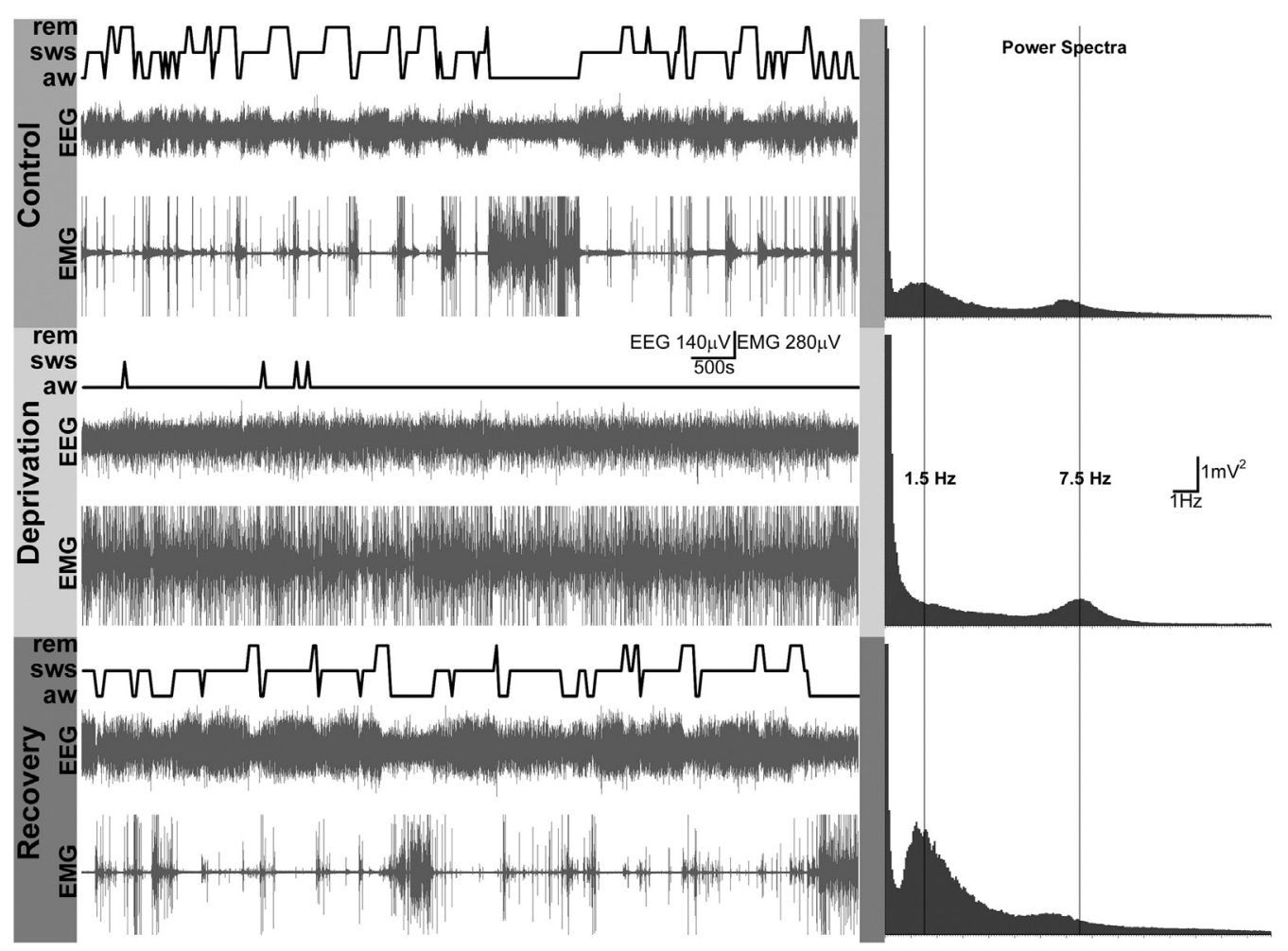

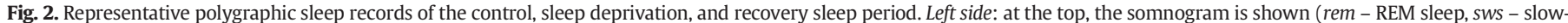

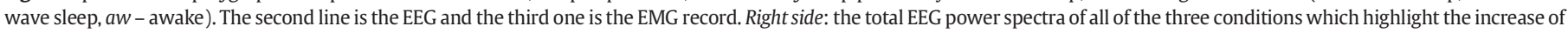
delta power due to rebound sleep in the recovery period during the first nocturnal period after sleep deprivation.

signal transduction (SD cortex: 1 protein, SD thalamus: 0, RS cortex: 6 , RS thalamus: 3 ) and miscellaneous (SD cortex: 5 proteins, SD thalamus: 0 , RS cortex: 14 , RS thalamus: 2 ).

Validation of the proteomics results was conducted using Western blot technique. We have assigned those proteins for validation experiments, the levels of which were showed unidirectional alterations in the proteomics experiments suggesting underlying protein expression changes. In sum, we successfully verified the level changes of selected proteins, i.e., Anxa3, Dpysl2, and Hspa8 (Fig. 7). On the other hand, no net change in the expression level of Dpysl2 was found in the RS parietal cortex and RS thalamus groups (Suppl. Fig. 1), which is in agreement with the observed bidirectional alteration of this protein in the above experiments (Tables 3 and 4, respectively), that points towards differential post-translational modifications in the background.

Moreover, we collected those proteins which are directly implicated in synaptic functions and plasticity (e.g., synaptic vesicle recycling, dendritic outgrowth and synaptogenesis). According to our results, these proteins comprise the $19 \%, 26 \%, 23 \%$ and $25 \%$ of proteins in the SD parietal cortex, SD thalamus, RS parietal cortex and RS thalamus groups, respectively (Fig. 8).

\section{Discussion}

4.1. Limitations and advantages of using synaptosome proteomics and sleep deprivation in sleep research

Results of our high-throughput proteomics study on synaptic protein level changes induced by sleep deprivation uncovered large-scale molecular alterations in the synapse. The extent of synaptic proteome changes suggests that sleep deprivation elicits a widespread but mild molecular reorganization of the synaptic region including even more proteins than expected. The interpretation of the results is limited because the available proteomic techniques can detect only more abundant proteins in a sample (Chevalier, 2010). Previous sleep-related studies on brain tissue proteome (Basheer et al., 2005; Pawlyk et al., 2007; Poirrier et al., 2008) were not synapse-specific since only a little portion of the brain protein content is synaptic. In addition, several synaptic proteins have wide distribution in other cell compartments and only a fraction of the synaptic proteome is strictly synapse-specific (see http://synprot.de). Therefore, the enrichment of synaptic proteins in the samples was carried out using cell fractionation technique. The applied synaptosome preparation is a good compromise at the actual state of technological development because it can give the widest scope to the synaptic region in its molecular complexity.

Gentle handling was used for sleep deprivation to avoid mixing the effects of sleep deprivation and the stress response. It is widely accepted that gentle handling is the optimal way of total sleep deprivation to minimize stress (Rechtschaffen et al., 1999; Fenzl et al., 2007); however, we cannot state that there is no stress at all after few hours of gentle handling. Our model was close to the clinically applied sleep deprivation method for treatment of depression (Giedke and Schwärzler, 2002), thus, we did not study an extremely severe sleep deprivation that would be very different from the human practice. Therefore, our proteomics data may have some relevance for translational studies as well.

4.2. Differences in the extent of alterations in the synaptic proteome between the parietal cortex and thalamus, moreover, between the SD and $R S$ groups

The neuronal plasticity, learning and cognitive processes extensively use the cerebral cortical synapses during waking. On the other hand, thalamus is a relay structure transmitting information to the cortex in wakefulness and maintains long-loop synchronization via thalamocortico-thalamic neuronal circuits (Steriade, 2006). These functional differences in information processing were reflected by our proteomics findings. The number of proteins changed in the parietal cortex was 

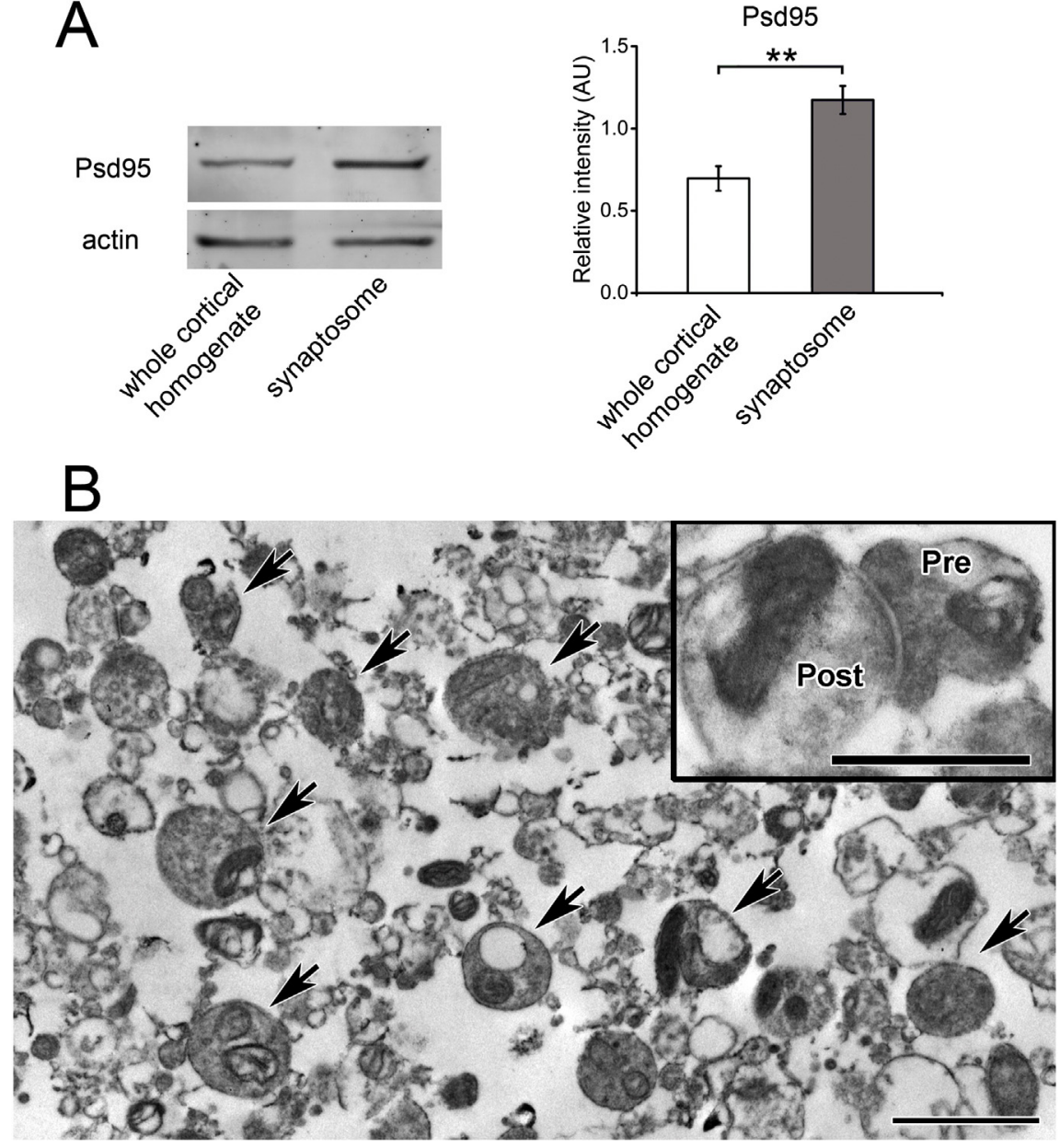

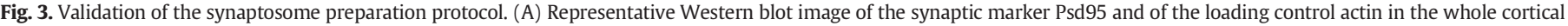

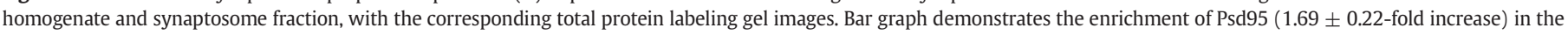

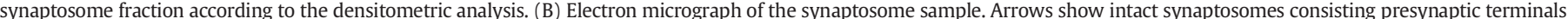

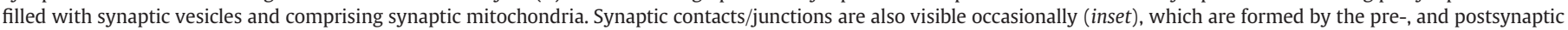
(Pre and Post, respectively) parts. Means \pm S.E.M. are presented; $n=5$ per group; ${ }^{* *} p<0.01$ in (A). Scale bar is $1 \mu \mathrm{m}$ and $0.5 \mu \mathrm{m}$ (inset) in (B).

higher (SD: 53, RS: 95) than that in the thalamus (SD: 19; RS: 28), suggesting that the higher the plasticity and learning intensity are, the higher the number of affected proteins is influenced by the sleepwake cycle. It is in agreement with the synaptic homeostasis hypothesis of sleep because it suggests that the extent of proteome changes in sleep deprivation is proportional to the intensity of information processing and learning.

To compare the two investigated time points, we can conclude that larger scale changes are prevalent at $16 \mathrm{~h}$ after the sleep deprivation than at the end of the deprivation procedure (Fig. 6A-D), presumably due to the recovery sleep period. On the other hand, this result also suggests that the timing of protein synthesis and degradation is delayed and/or these processes progress after the end of the sleep deprivation. Therefore, our data shows that an unexpectedly long and complex procedure of synaptic proteome adjustment takes place after sleep deprivation, although, we cannot separate the delayed protein synthesis changes induced by sleep deprivation from the long-term effect of the lack of sleep.

\subsection{The importance of the most abundant functional clusters of SD and RS proteins}

Several categories of cellular functions were revealed with numerous proteins representing them. In most of the experimental situations, the majority of significant protein changes were related to carbohydrate and energy metabolism, protein synthesis and folding and the cytoskeletal functional clusters, besides synaptic transmission (Fig. 6). The enrichment of these general cellular functions suggests that fundamental physiological mechanisms are influenced by sleep deprivation in the synapse.

Sleep serves as a lower energy consuming state, which is demanded after the awake period, characterized as a state with higher metabolic rates (Madsen et al., 1991; Maquet, 1995; Benington and Heller, 1995); and synaptic metabolism is a good index of synaptic molecular reorganization in sleep. Consequently, lower ATP levels in sleep deprivation and waking, and higher in sleep and recovery sleep after deprivation have been demonstrated previously (Dworak et al., 2010). Local metabolic differences between distinct brain areas are known, and the cerebral cortex is one of the regions, which show high fluctuation of metabolic rates throughout the sleep-wake cycle (Braun et al., 1997; Vyazovskiy et al., 2008). In all experimental situations, remarkable changes in the amount of proteins were unveiled which are involved in the carbohydrate and energy metabolism, however the highest number of changes were found in metabolic proteins in the parietal cortex in $\mathrm{RS}(n=26)$ and in SD $(n=17)$ (Fig. $6 \mathrm{E}, \mathrm{G})$. Interestingly, most of the thalamic proteins implicated in these functions in RS group showed decreased levels (Table 4). Altogether, these data are in accordance with the fact that synapses are extremely energy-sensitive 

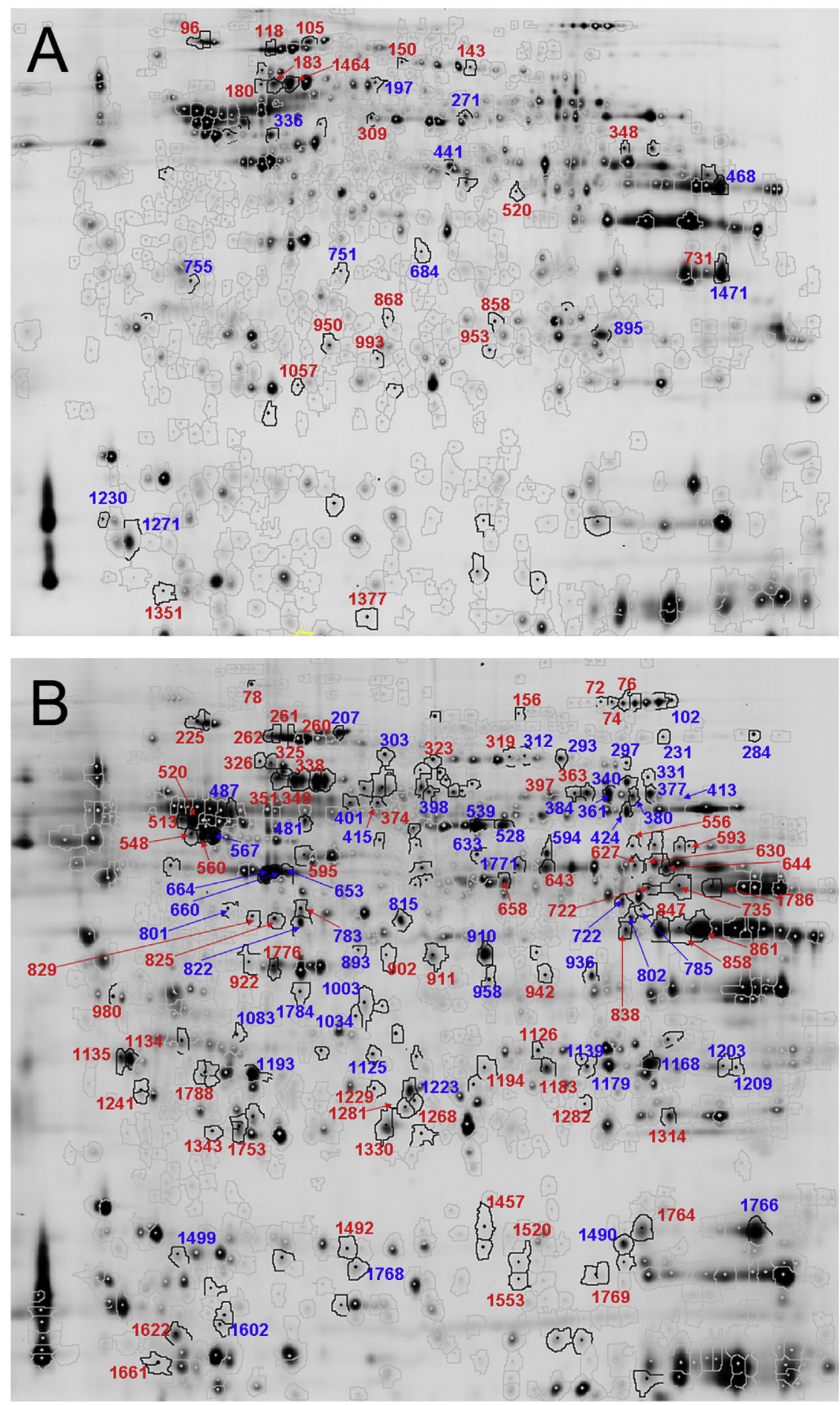

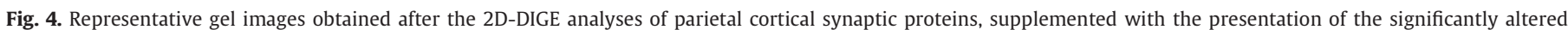

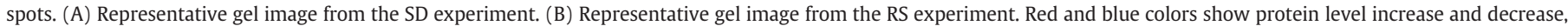
respectively.

cell compartments and assumes that the functional alternation of synapses in sleep-wake cycle is accompanied by changes in synaptic metabolism.

Sleep is suggested to have a considerable influence on the remodeling of the neural cytoskeleton, supported by the observed alterations in the number and morphology of the dendritic spines (Bushey et al., 2011; Maret et al., 2011). This is in agreement with the fact that sleep promotes neural plasticity (Benington and Frank, 2003) and plasticity requires dynamic morphological changes (Yang et al., 2009; Kasai et al., 2010). Extensive cytoskeletal changes in all experimental groups were demonstrated (Fig. 6). Several major components of the cytoskeleton are influenced (e.g., actin and tubulin) while a huge repertoire of other proteins are mainly associated with the precise regulation of the cytoskeletal structure or related to the transport mechanisms along the cytoskeleton. It should be noted that certain proteins are already revealed as potential regulators of synaptogenesis and the structure of 

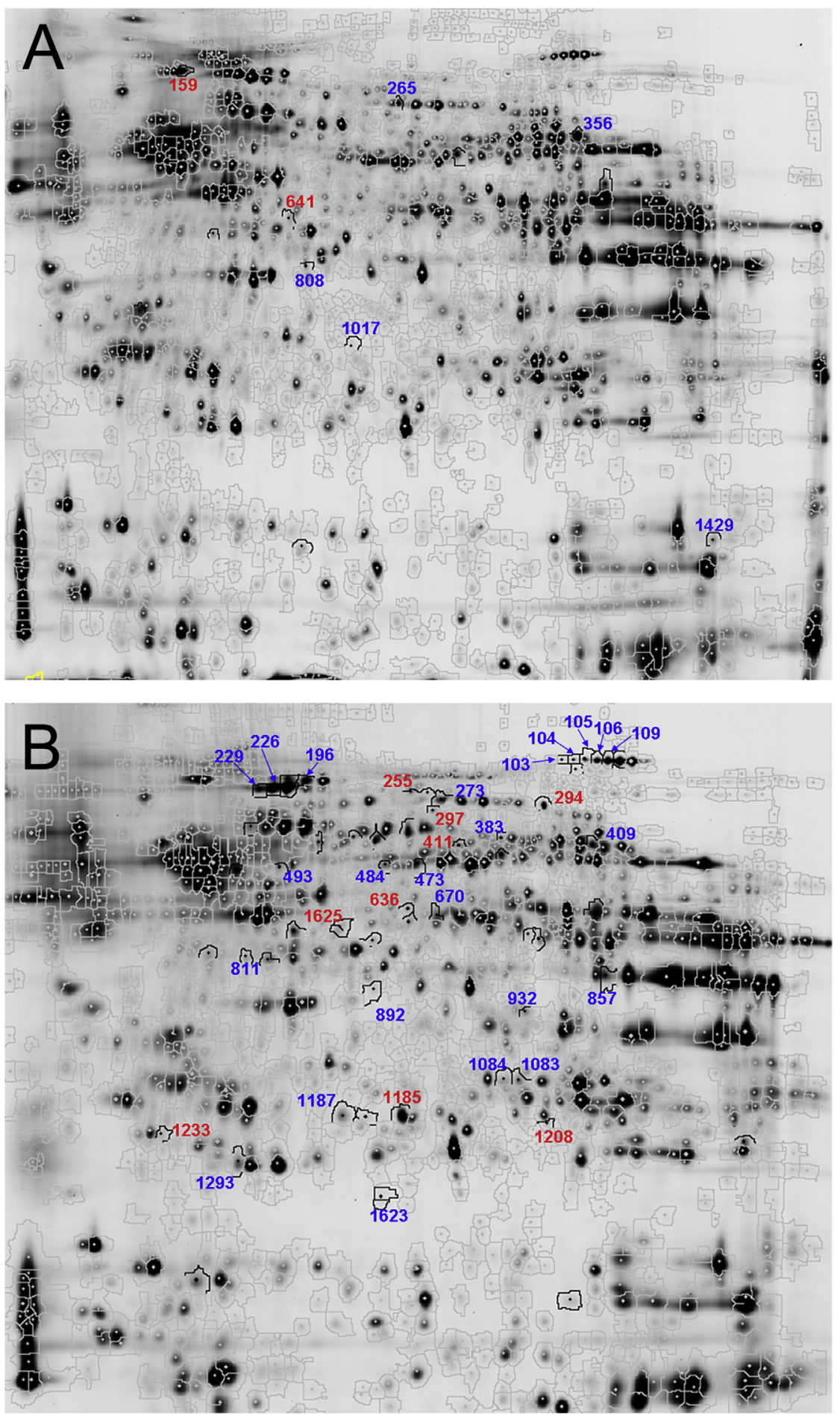

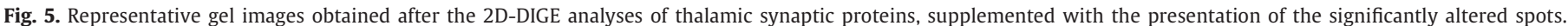

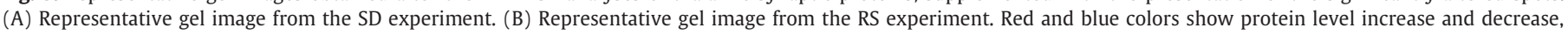
respectively. (For interpretation of the references to colors in this figure legend, the reader is referred to the web version of this article.)

existing synapses (Tables 1-4, and Fig. 8). A general decrease was also found in the levels of cytoskeletal and motility-related proteins in the parietal cortex of SD compared to undisturbed rats (Table 1), supporting an inhibited structural remodeling of synapses due to sleep deprivation.

Another hypothesis of sleep function is the "free radical flux theory" which raises that sleep is initiated by free radical level increase, and sleep has a function to eliminate them (Reimund, 1994; Ikeda et al., 2005). The most oxidative stress response-related proteins were found in the parietal cortex of RS group animals, ( $n=9$, Fig. 6 ) among which 7 protein showed level increase. This is in agreement with previous examinations and theories, that concluded antioxidant responses after sleep deprivation, as a consequence of the higher metabolic rate related to prolonged wakefulness (Reimund, 1994; Brown and Naidoo, 
Table 1

List of significantly altered SD synaptic proteins from the parietal cortex, assigned to functional groups.

\begin{tabular}{|c|c|c|c|c|c|}
\hline Protein name & $\begin{array}{l}\text { Gene } \\
\text { name }\end{array}$ & $\begin{array}{l}\text { Accession } \\
\text { number }\end{array}$ & $\begin{array}{l}\text { Up/down } \\
\text { regulation }\end{array}$ & Cellular localization & Cellular function \\
\hline \multicolumn{6}{|l|}{ Carbohydrate and energy metabolism } \\
\hline Fructose-bisphosphate aldolase A & Aldoa & P05065 & $\uparrow \downarrow$ & Cytoplasm & Glycolysis \\
\hline Fructose-bisphosphate aldolase C & Aldoc & P09117 & $\uparrow$ & Cytoplasm & Glycolysis \\
\hline ATP synthase subunit alpha, mitochondrial & Atp5a1 & P15999 & $\downarrow$ & Mitochondrion & Energy metabolism \\
\hline ATP synthase subunit delta, mitochondrial & Atp5d & P35434 & $\downarrow$ & Mitochondrion & Energy metabolism \\
\hline ATP synthase subunit $d$, mitochondrial & Atp5h & P31399 & $\uparrow$ & Mitochondrion & Energy metabolism \\
\hline Creatine kinase B-type & $\mathrm{Ckb}$ & P07335 & $\downarrow$ & Cytoplasm & Energy metabolism \\
\hline Creatine kinase U-type, mitochondrial & Ckmt1 & P30275 & $\downarrow$ & Mitochondrion & Energy metabolism \\
\hline Alpha-enolase & Eno1 & P04764 & $\uparrow \downarrow$ & Cytoplasm & Glycolysis \\
\hline $\begin{array}{l}\text { Electron transfer flavoprotein subunit alpha, } \\
\text { mitochondrial }\end{array}$ & Etfa & P13803 & $\uparrow$ & Mitochondrion & Electron transport \\
\hline Fumarate hydratase, mitochondrial & Fh & P14408 & $\uparrow$ & Mitochondrion & $\begin{array}{l}\text { Carbohydrate metabolism, involved in } \\
\text { tricarboxylic acid cycle }\end{array}$ \\
\hline $\begin{array}{l}\text { Glyceraldehyde-3-phosphate } \\
\text { dehydrogenase }\end{array}$ & Gapdh & P04797 & $\downarrow$ & Cytoplasm & Glycolysis \\
\hline Malate dehydrogenase, cytoplasmic & Mdh1 & 088989 & $\uparrow$ & Cytoplasm & $\begin{array}{l}\text { Carbohydrate metabolism, involved in } \\
\text { malate-aspartate shuttle }\end{array}$ \\
\hline Malate dehydrogenase, mitochondrial & Mdh2 & P04636 & $\downarrow$ & Mitochondrion & $\begin{array}{l}\text { Carbohydrate metabolism, involved in } \\
\text { tricarboxylic acid cycle and malate-aspartate } \\
\text { shuttle }\end{array}$ \\
\hline Phosphoglycerate kinase 1 & Pgk1 & P16617 & $\downarrow$ & Cytoplasm & Glycolysis \\
\hline Pyruvate kinase isozymes M1/M2 & Pkm2 & P11980 & $\uparrow$ & Cytoplasm & Glycolysis \\
\hline $\begin{array}{l}\text { Cytochrome b-c1 complex subunit } 1 \text {, } \\
\text { mitochondrial }\end{array}$ & Uqcrc1 & Q68FY0 & $\downarrow$ & Mitochondrion & Electron transport \\
\hline $\begin{array}{l}\text { Cytochrome b-c1 complex subunit } 2 \text {, } \\
\text { mitochondrial }\end{array}$ & Uqcrc2 & P32551 & $\downarrow$ & Mitochondrion & Electron transport \\
\hline \multicolumn{6}{|l|}{ Amino acid metabolism } \\
\hline Aminoacylase-1A & Acy1a & Q6AYS7 & $\downarrow$ & Cytoplasm & Deacetylation of amino acids \\
\hline $\begin{array}{l}\text { 3-Hydroxyisobutyrate dehydrogenase, } \\
\text { mitochondrial }\end{array}$ & Hibadh & P29266 & $\uparrow$ & Mitochondrion & Amino acid metabolism \\
\hline $\begin{array}{l}\text { Isovaleryl-CoA dehydrogenase, } \\
\text { mitochondrial }\end{array}$ & Ivd & P12007 & $\downarrow$ & Mitochondrion & Amino acid metabolism \\
\hline \multicolumn{6}{|l|}{ Lipid metabolism } \\
\hline Enoyl-CoA hydratase, mitochondrial & Echs1 & P14604 & $\uparrow$ & Mitochondrion & Fatty acid metabolism \\
\hline \multicolumn{6}{|l|}{ Nucleotide metabolism } \\
\hline $\begin{array}{l}\text { 2'.3'-cyclic-nucleotide } \\
\text { 3'-phosphodiesterase }\end{array}$ & Cnp & P13233 & $\uparrow$ & Cytoplasm & $\begin{array}{l}\text { RNA processing, cytoskeletal organization, } \\
\text { neurite outgrowth }\end{array}$ \\
\hline Guanine deaminase & Gda & Q9WTT6 & $\downarrow$ & Cytoplasm & $\begin{array}{l}\text { Nucleotide metabolism, regulation of the } \\
\text { cytoskeleton, dendritic arborization }\end{array}$ \\
\hline \multicolumn{6}{|l|}{ Synaptic transmission } \\
\hline V-type proton ATPase subunit E 1 & Atp6v1e1 & Q6PCU2 & $\uparrow$ & $\begin{array}{l}\text { Cytoplasm, membrane of } \\
\text { intracellular compartments, } \\
\text { mitochondrion }\end{array}$ & $\begin{array}{l}\text { Neurotransmitter uptake into synaptic vesicles, } \\
\text { pH regulation in intracellular compartments }\end{array}$ \\
\hline Dihydropyrimidinase-related protein 2 & Dpysl2 & P47942 & $\uparrow \uparrow \uparrow$ & Cytoplasm & $\begin{array}{l}\text { Neurite outgrowth, synaptic vesicle exocytosis, } \\
\text { receptor recycling }\end{array}$ \\
\hline Septin-11 & Sept11 & B3GNI6 & $\downarrow$ & Cytoplasm & $\begin{array}{l}\text { Regulation of the dendritic arborization and } \\
\text { neurite outgrowth, synaptic vesicle trafficking }\end{array}$ \\
\hline Neuronal-specific septin-3 & Sept3 & Q9WU34 & $\downarrow$ & Cytoplasm & Synaptic vesicle recycling \\
\hline Alpha-synuclein & Snca & P37377 & $\downarrow$ & Cytoplasm & $\begin{array}{l}\text { Modulation of synaptic vesicle exocytosis, } \\
\text { receptor recycling, microtubular organization }\end{array}$ \\
\hline \multicolumn{6}{|l|}{ Protein synthesis and folding } \\
\hline Endoplasmic reticulum resident protein 29 & Erp29 & P52555 & $\uparrow$ & Endoplasmic reticulum & $\begin{array}{l}\text { Processing of secreted and endomembrane } \\
\text { proteins, response to stress }\end{array}$ \\
\hline 78 kDa glucose-regulated protein & Hspa5 & P06761 & $\uparrow$ & Endoplasmic reticulum & Protein folding \\
\hline Heat shock cognate $71 \mathrm{kDa}$ protein & Hspa8 & P63018 & $\uparrow \uparrow$ & Cytoplasm & Protein folding, macromolecular assembly \\
\hline Stress-70 protein, mitochondrial & Hspa9 & P48721 & $\uparrow$ & Mitochondrion & Protein folding, macromolecular assembly \\
\hline $60 \mathrm{kDa}$ heat shock protein, mitochondrial & Hspd1 & P63039 & $\uparrow \uparrow \uparrow$ & Mitochondrion & Folding of mitochondrial proteins \\
\hline Protein DJ-1 & Park7 & 088767 & $\uparrow$ & Cytoplasm, mitochondrion & $\begin{array}{l}\text { Chaperone function, response to oxidative } \\
\text { stress, dopaminergic synaptic transmission }\end{array}$ \\
\hline Poly(rC)-binding protein 1 & Pcbp1 & P60335 & $\uparrow$ & Cytoplasm, nucleus & RNA processing, regulation of protein synthesis \\
\hline Protein disulfide-isomerase A3 & Pdia3 & P11598 & $\downarrow$ & Endoplasmic reticulum, nucleus & Protein folding, macromolecular assembly \\
\hline 40S ribosomal protein S16 & Rps16 & P62250 & $\downarrow$ & Cytoplasm & Protein synthesis \\
\hline Transcription elongation factor B polypeptide 2 & Tceb2 & P62870 & $\downarrow$ & Nucleus & Protein synthesis \\
\hline \multicolumn{6}{|l|}{ Response to oxidative stress } \\
\hline Peroxiredoxin-6 & Prdx6 & 035244 & $\uparrow$ & Cytoplasm & Response to oxidative stress \\
\hline \multicolumn{6}{|l|}{ Cytoskeletal protein } \\
\hline Actin, cytoplasmic 1 & Actb & P60711 & $\downarrow$ & Cytoplasm & Microfilamental component \\
\hline ADP-ribosylation factor 3 & Arf3 & P61206 & $\downarrow$ & Golgi apparatus, cytoplasm & $\begin{array}{l}\text { Vesicle trafficking, exocytosis, organization of } \\
\text { the actin cytoskeleton }\end{array}$ \\
\hline F-actin-capping protein subunit beta & Capzb & Q5XI32 & $\downarrow$ & Cytoplasm & Microfilament organization, synaptic remodelling \\
\hline
\end{tabular}


Table 1 (continued)

\begin{tabular}{|c|c|c|c|c|c|}
\hline Protein name & $\begin{array}{l}\text { Gene } \\
\text { name }\end{array}$ & $\begin{array}{l}\text { Accession } \\
\text { number }\end{array}$ & $\begin{array}{l}\text { Up/down } \\
\text { regulation }^{\mathrm{a}}\end{array}$ & Cellular localization & Cellular function \\
\hline Myelin basic protein $S$ & Mbp & P02688 & $\downarrow \downarrow$ & Cytoplasm & Regulation of microfilaments and microtubules \\
\hline Myosin light polypeptide 6 & Myl6 & Q64119 & $\downarrow$ & Cytoplasm & Motor protein function \\
\hline Profilin-2 & Pfn2 & Q9EPC6 & $\uparrow$ & Cytoplasm & $\begin{array}{l}\text { Regulation of microfilaments, synaptogenesis, } \\
\text { neurite outgrowth, synaptic vesicle exocytosis, } \\
\text { receptor trafficking }\end{array}$ \\
\hline Myosin regulatory light chain RLC-A & Rlc-a & P13832 & $\downarrow$ & Cytoplasm & Motor protein regulation \\
\hline Tubulin beta- 5 chain & Tubb5 & P69897 & $\uparrow \downarrow$ & Cytoplasm & Microtubular component \\
\hline \multicolumn{6}{|l|}{ Signal transduction } \\
\hline Calcineurin subunit B type 1 & Ppp3r1 & P63100 & $\downarrow$ & Cytoplasm & Regulation of several signaling pathways \\
\hline \multicolumn{6}{|l|}{ Miscellaneous } \\
\hline Annexin A3 & Anxa3 & P14669 & $\downarrow$ & Cytoplasm & $\begin{array}{l}\text { Regulation of intracellular calcium levels, } \\
\text { signal transduction }\end{array}$ \\
\hline Histone H2B type 1 & Hist1h2bh & Q00715 & $\downarrow$ & Nucleus & Component of the nucleosome \\
\hline $\begin{array}{l}\text { Voltage-dependent anion-selective channel } \\
\text { protein } 1\end{array}$ & Vdac1 & Q9Z2L0 & $\uparrow \uparrow \uparrow \downarrow$ & $\begin{array}{l}\text { Mitochondrion, plasma } \\
\text { membrane }\end{array}$ & Modulation of intracellular calcium levels \\
\hline $\begin{array}{l}\text { Voltage-dependent anion-selective channel } \\
\text { protein } 2\end{array}$ & Vdac2 & P81155 & $\uparrow \uparrow \uparrow \downarrow$ & Mitochondrion & Modulation of intracellular calcium levels \\
\hline WD repeat-containing protein 61 & Wdr61 & Q4V7A0 & $\downarrow$ & Cytoplasm, nucleus & Histone methylation \\
\hline
\end{tabular}

a Directions of alterations in the levels of the corresponding protein spots (due to expression changes or post-translational modifications).

2010; Ramanathan et al., 2010; Ramanathan and Siegel, 2011). This result draws attention on a high level of impairment in the oxidative homeostasis which is even more pronounced later after sleep deprivation termination. It is also important to note that besides the defending role of these enzymes, some of them might be involved in synaptic plasticity, due to the fact that reactive oxygen species can serve as messenger

Table 2

List of significantly altered SD synaptic proteins from the thalamus, assigned to functional groups.

\begin{tabular}{|c|c|c|c|c|c|}
\hline Protein name & $\begin{array}{l}\text { Gene } \\
\text { name }\end{array}$ & $\begin{array}{l}\text { Accession } \\
\text { number }\end{array}$ & $\begin{array}{l}\text { Up/down } \\
\text { regulation }^{\mathrm{a}}\end{array}$ & Cellular localization & Cellular function \\
\hline \multicolumn{6}{|l|}{ Carbohydrate and energy metabolism } \\
\hline $\begin{array}{l}\text { ATP synthase subunit alpha, } \\
\text { mitochondrial }\end{array}$ & Atp5a1 & P15999 & $\downarrow$ & Mitochondrion & Energy metabolism \\
\hline Malate dehydrogenase, cytoplasmic & Mdh1 & 088989 & $\downarrow$ & Cytoplasm & $\begin{array}{l}\text { Carbohydrate metabolism, involved in } \\
\text { malate-aspartate shuttle }\end{array}$ \\
\hline \multicolumn{6}{|l|}{ Amino acid metabolism } \\
\hline Glutamine synthetase & Glul & P09606 & $\downarrow$ & Cytoplasm, mitochondrion & Amino acid metabolism \\
\hline \multicolumn{6}{|l|}{ Nucleotide metabolism } \\
\hline $3^{\prime}\left(2^{\prime}\right) \cdot 5^{\prime}$-bisphosphate nucleotidase 1 & Bpnt1 & Q9Z1N4 & $\uparrow$ & Cytoplasm & Nucleotide metabolism, sulphate metabolism \\
\hline \multicolumn{6}{|l|}{ Synaptic transmission } \\
\hline Dihydropyrimidinase-related protein 2 & Dpysl2 & P47942 & $\downarrow$ & Cytoplasm & $\begin{array}{l}\text { Neurite outgrowth, synaptic vesicle exocytosis, } \\
\text { receptor recycling }\end{array}$ \\
\hline Septin-6 & Sept6 & Q9R1T4 & $\uparrow$ & Cytoplasm & Synaptic vesicle recycling, neurite outgrowth \\
\hline Synapsin-2 & Syn2 & Q63537 & $\downarrow$ & Cytoplasm & Synaptic vesicle docking \\
\hline \multicolumn{6}{|l|}{ Protein synthesis and folding } \\
\hline $\begin{array}{l}\text { Endoplasmic reticulum resident protein } \\
29\end{array}$ & Erp29 & P52555 & $\downarrow$ & Endoplasmic reticulum & $\begin{array}{l}\text { Processing of secreted and endomembrane } \\
\text { proteins, response to stress }\end{array}$ \\
\hline $78 \mathrm{kDa}$ glucose-regulated protein & Hspa5 & P06761 & $\uparrow$ & Endoplasmic reticulum & Protein folding \\
\hline $\begin{array}{l}\text { Mesencephalic astrocyte-derived } \\
\text { neurotrophic factor }\end{array}$ & Manf & P0С5H9 & $\downarrow$ & $\begin{array}{l}\text { Endoplasmic reticulum, cytoplasm, } \\
\text { extracellular space }\end{array}$ & Protein folding, stress response \\
\hline $\begin{array}{l}\text { Peptidyl-prolyl cis-trans isomerase } \\
\text { NIMA-interacting } 1\end{array}$ & Pin1 & Q13526 & $\downarrow$ & Cytoplasm, nucleus & $\begin{array}{l}\text { Regulation of protein synthesis and cytoskeletal } \\
\text { structure }\end{array}$ \\
\hline Peptidyl-prolyl cis-trans isomerase A & Ppia & P10111 & $\downarrow$ & Cytoplasm & $\begin{array}{l}\text { Protein folding, regulation of the cytoskeleton, } \\
\text { molecular trafficking }\end{array}$ \\
\hline $60 \mathrm{~S}$ acidic ribosomal protein $\mathrm{P} 0$ & Rplp0 & P19945 & $\downarrow$ & Cytoplasm, nucleus & Regulation of protein synthesis \\
\hline $\begin{array}{l}\text { Sorting and assembly machinery } \\
\text { component } 50 \text { homolog }\end{array}$ & Samm50 & Q6AXV4 & $\downarrow$ & Mitochondrion & Assembly of mitochondrial proteins \\
\hline \multicolumn{6}{|l|}{ Proteolysis } \\
\hline Cathepsin D & Ctsd & P24268 & $\uparrow$ & Cytoplasm & $\begin{array}{l}\text { Lysosomal protein degradation, synaptic } \\
\text { transmission }\end{array}$ \\
\hline Ubiquitin-conjugating enzyme E2 L3 & Ube213 & P68036 & $\downarrow$ & Cytoplasm, nucleus & Ubiquitination \\
\hline \multicolumn{6}{|l|}{ Cytoskeletal protein } \\
\hline Actin, cytoplasmic 1 & Actb & P60711 & $\uparrow$ & Cytoplasm & Microfilamental component \\
\hline F-actin-capping protein subunit alpha-2 & Capza2 & Q3T1K5 & $\downarrow$ & Cytoplasm & Microfilament organization \\
\hline Destrin & Dstn & Q7M0E3 & $\downarrow$ & Cytoplasm & $\begin{array}{l}\text { Microfilament organization, receptor trafficking, } \\
\text { dendrite formation }\end{array}$ \\
\hline
\end{tabular}

\footnotetext{
${ }^{a}$ Directions of alterations in the levels of the corresponding protein spots (due to expression changes or post-translational modifications).
} 
Table 3

List of significantly altered RS synaptic proteins from the parietal cortex, assigned to functional groups.

\begin{tabular}{|c|c|c|c|c|c|}
\hline Protein name & $\begin{array}{l}\text { Gene } \\
\text { name }\end{array}$ & $\begin{array}{l}\text { Accession } \\
\text { number }\end{array}$ & $\begin{array}{l}\text { Up/down } \\
\text { regulation }\end{array}$ & Cellular localization & Cellular function \\
\hline \multicolumn{6}{|l|}{ Carbohydrate and energy metabolism } \\
\hline Aconitate hydratase, mitochondrial & Aco2 & Q9ER34 & $\uparrow \uparrow \uparrow \downarrow$ & Mitochondrion & Involved in tricarboxylic acid cycle \\
\hline Fructose-bisphosphate aldolase A & Aldoa & P05065 & $\uparrow \uparrow$ & Cytoplasm & Glycolysis \\
\hline Fructose-bisphosphate aldolase C & Aldoc & P09117 & $\downarrow \downarrow \downarrow$ & Cytoplasm & Glycolysis \\
\hline ATP synthase subunit alpha, mitochondrial & Atp5a1 & P15999 & $\downarrow$ & Mitochondrion & Energy metabolism \\
\hline ATP synthase subunit beta, mitochondrial & Atp5b & P10719 & $\downarrow \downarrow \uparrow$ & Mitochondrion & Energy metabolism \\
\hline ATP synthase subunit d, mitochondrial & Atp5h & P31399 & $\uparrow$ & Mitochondrion & Energy metabolism \\
\hline Creatine kinase B-type & $\mathrm{Ckb}$ & P07335 & $\uparrow$ & Cytoplasm & Energy metabolism \\
\hline Creatine kinase U-type, mitochondrial & Ckmt1 & P30275 & $\uparrow \uparrow$ & Mitochondrion & Energy metabolism \\
\hline $\begin{array}{l}\text { Dihydrolipoyllysine-residue } \\
\text { acetyltransferase component of pyruvate } \\
\text { dehydrogenase complex, mitochondrial }\end{array}$ & Dlat & P08461 & $\downarrow$ & Mitochondrion & Carbohydrate metabolism \\
\hline $\begin{array}{l}\text { Dihydrolipoyl dehydrogenase, } \\
\text { mitochondrial }\end{array}$ & Dld & Q6P6R2 & $\uparrow \downarrow$ & Mitochondrion & Involved in tricarboxylic acid cycle \\
\hline Alpha-enolase & Eno1 & P04764 & $\downarrow \downarrow \uparrow$ & Cytoplasm & Glycolysis \\
\hline Gamma-enolase & Eno2 & P07323 & $\uparrow \uparrow \downarrow$ & Cytoplasm & Glycolysis \\
\hline $\begin{array}{r}\text { Fumarylacetoacetate hydrolase } \\
\text { domain-containing protein } 2\end{array}$ & Fahd2 & B2RYW9 & $\downarrow \downarrow \uparrow$ & Mitochondrion & Carbohydrate and amino acid metabolism \\
\hline Fumarate hydratase, mitochondrial & Fh & P14408 & $\uparrow \uparrow \downarrow$ & Mitochondrion & $\begin{array}{l}\text { Carbohydrate metabolism, involved in } \\
\text { tricarboxylic acid cycle }\end{array}$ \\
\hline $\begin{array}{l}\text { Glyceraldehyde-3-phosphate } \\
\text { dehydrogenase }\end{array}$ & Gapdh & P04797 & $\downarrow \downarrow \downarrow \uparrow$ & Cytoplasm & Glycolysis \\
\hline $\begin{array}{l}\text { Isocitrate dehydrogenase [NAD] subunit } \\
\text { alpha, mitochondrial }\end{array}$ & Idh3a & Q99NA5 & $\downarrow \downarrow$ & Mitochondrion & Involved in tricarboxylic acid cycle \\
\hline $\begin{array}{l}\text { Isocitrate dehydrogenase [NAD] subunit } \\
\text { beta, mitochondrial }\end{array}$ & Idh3b & Q68FX0 & $\uparrow$ & Mitochondrion & Involved in tricarboxylic acid cycle \\
\hline Malate dehydrogenase, cytoplasmic & Mdh1 & 088989 & $\uparrow \uparrow \downarrow$ & Cytoplasm & $\begin{array}{l}\text { Carbohydrate metabolism, involved in } \\
\text { malate-aspartate shuttle }\end{array}$ \\
\hline Malate dehydrogenase, mitochondrial & Mdh2 & P04636 & $\downarrow$ & Mitochondrion & $\begin{array}{l}\text { Carbohydrate metabolism, involved in tricarboxylic } \\
\text { acid cycle and malate-aspartate shuttle }\end{array}$ \\
\hline $\begin{array}{l}\text { Succinyl-CoA:3-ketoacid-coenzyme A } \\
\text { transferase } 1 \text {, mitochondrial }\end{array}$ & Oxct1 & B2GV06 & $\downarrow$ & Mitochondrion & Metabolism of ketone bodies \\
\hline $\begin{array}{l}\text { Pyruvate dehydrogenase E1 component } \\
\text { subunit alpha, somatic form, mitochondrial }\end{array}$ & Pdha1 & P35486 & $\uparrow \uparrow \uparrow \uparrow \downarrow \downarrow$ & Mitochondrion & $\begin{array}{l}\text { Involved in carbohydrate and fatty acid } \\
\text { metabolism }\end{array}$ \\
\hline $\begin{array}{l}\text { Pyruvate dehydrogenase E1 component } \\
\text { subunit beta, mitochondrial }\end{array}$ & Pdhb & P49432 & $\uparrow \downarrow$ & Mitochondrion & $\begin{array}{l}\text { Involved in carbohydrate and fatty acid } \\
\text { metabolism }\end{array}$ \\
\hline Phosphoglycerate mutase 1 & Pgam1 & P25113 & $\uparrow$ & Cytoplasm & Carbohydrate metabolism, glycolysis \\
\hline Phosphoglycerate kinase 1 & Pgk1 & P16617 & $\uparrow \uparrow$ & Cytoplasm & Glycolysis \\
\hline Pyruvate kinase isozymes M1/M2 & Pkm2 & P11980 & $\downarrow \downarrow$ & Cytoplasm & Glycolysis \\
\hline Triosephosphate isomerase & Tpi1 & P48500 & $\uparrow \uparrow \downarrow \downarrow$ & Cytoplasm & Glycolysis \\
\hline \multicolumn{6}{|l|}{ Amino acid metabolism } \\
\hline Glutamine synthetase & Glul & P09606 & $\uparrow \uparrow \downarrow \downarrow$ & Cytoplasm, mitochondrion & Amino acid metabolism \\
\hline Aspartate aminotransferase, cytoplasmic & Got1 & P13221 & $\uparrow$ & Cytoplasm & Amino acid metabolism \\
\hline \multicolumn{6}{|l|}{ Lipid metabolism } \\
\hline Enoyl-CoA hydratase, mitochondrial & Echs1 & P14604 & $\uparrow$ & Mitochondrion & Fatty acid metabolism \\
\hline \multicolumn{6}{|l|}{ Nucleotide metabolism } \\
\hline Adenylate kinase isoenzyme 1 & Ak1 & P39069 & $\uparrow$ & Cytoplasm & Nucleotide metabolism, energy metabolism \\
\hline \multicolumn{6}{|l|}{ Synaptic transmission } \\
\hline $\begin{array}{l}\text { V-type proton ATPase subunit B, brain } \\
\text { isoform }\end{array}$ & Atp6v1b2 & P62815 & $\downarrow \downarrow$ & $\begin{array}{l}\text { Cytoplasm, membrane of } \\
\text { intracellular compartments, } \\
\text { mitochondrion }\end{array}$ & $\begin{array}{l}\text { Neurotransmitter uptake into synaptic vesicles, } \\
\mathrm{pH} \text { regulation in intracellular compartments }\end{array}$ \\
\hline Dihydropyrimidinase-related protein 2 & Dpysl2 & P47942 & $\uparrow \uparrow \downarrow$ & Cytoplasm & $\begin{array}{l}\text { Neurite outgrowth, synaptic vesicle exocytosis, } \\
\text { receptor recycling }\end{array}$ \\
\hline Gamma-soluble NSF attachment protein & Napg & Q9CWZ7 & $\uparrow \uparrow$ & Cytoplasm & Vesicular transport, synaptic vesicle exocytosis \\
\hline Adaptin ear-binding coat-associated protein 1 & Necap1 & P69682 & $\downarrow$ & Cytoplasm & Synaptic vesicle endocytosis \\
\hline Endophilin-A1 & Sh3gl2 & 035179 & $\uparrow$ & Cytoplasm & Synaptic vesicle recycling \\
\hline Synaptosomal-associated protein 25 & Snap25 & P60881 & $\uparrow \uparrow$ & Cytoplasm & Synaptic vesicle exocytosis \\
\hline Synapsin-1 & Syn1 & P09951 & $\uparrow \downarrow$ & Cytoplasm & Synaptic vesicle docking \\
\hline Synapsin-2 & Syn2 & Q63537 & $\downarrow \downarrow \downarrow$ & Cytoplasm & Synaptic vesicle docking \\
\hline Thy-1 membrane glycoprotein & Thy1 & P01830 & $\uparrow$ & Cytoplasm & $\begin{array}{l}\text { Synaptic vesicle exocytosis, modulation of the } \\
\text { cytoskeleton }\end{array}$ \\
\hline \multicolumn{6}{|l|}{ Protein synthesis and folding } \\
\hline Elongation factor 1-beta & Eef1b & 070251 & $\uparrow$ & Cytoplasm & Protein synthesis \\
\hline Eukaryotic translation initiation factor $4 \mathrm{H}$ & Eif4h & Q5XI72 & $\downarrow$ & Cytoplasm & Protein synthesis \\
\hline 78 kDa glucose-regulated protein & Hspa5 & P06761 & $\uparrow$ & Endoplasmic reticulum & Protein folding \\
\hline Heat shock cognate $71 \mathrm{kDa}$ protein & Hspa8 & P63018 & $\uparrow \uparrow \uparrow$ & Cytoplasm & Protein folding, macromolecular assembly \\
\hline Stress-70 protein, mitochondrial & Hspa9 & P48721 & $\downarrow$ & Mitochondrion & Protein folding, macromolecular assembly \\
\hline $60 \mathrm{kDa}$ heat shock protein, mitochondrial & Hspd1 & P63039 & $\uparrow \uparrow \downarrow$ & Mitochondrion & Folding of mitochondrial proteins \\
\hline Protein disulfide-isomerase A3 & Pdia3 & P11598 & $\uparrow \downarrow$ & $\begin{array}{l}\text { Endoplasmic reticulum, } \\
\text { nucleus }\end{array}$ & Protein folding, macromolecular assembly \\
\hline Prefoldin subunit 2 & $\operatorname{Pfdn} 2$ & B0BN18 & $\uparrow$ & Cytoplasm, mitochondrion, & Posttranslational processing of actin and tubulin \\
\hline
\end{tabular}


Table 3 (continued)

\begin{tabular}{|c|c|c|c|c|c|}
\hline Protein name & $\begin{array}{l}\text { Gene } \\
\text { name }\end{array}$ & $\begin{array}{l}\text { Accession } \\
\text { number }\end{array}$ & $\begin{array}{l}\text { Up/down } \\
\text { regulation }^{\text {a }}\end{array}$ & Cellular localization & Cellular function \\
\hline & & & & nucleus & monomers \\
\hline Peptidyl-prolyl cis-trans isomerase A & Ppia & P10111 & $\uparrow$ & Cytoplasm & $\begin{array}{l}\text { Regulation of the cytoskeleton, molecular } \\
\text { trafficking, protein folding }\end{array}$ \\
\hline Peptidyl-prolyl cis-trans isomerase D & Ppid & Q6DGG0 & $\downarrow$ & Cytoplasm & Protein folding, regulation of chaperone proteins \\
\hline Stress-induced-phosphoprotein 1 & Stip1 & O35814 & $\downarrow$ & Cytoplasm & Chaperone function \\
\hline \multicolumn{6}{|l|}{ Proteolysis } \\
\hline Proteasome subunit beta type- 4 & Psmb4 & P34067 & $\uparrow$ & Cytoplasm & Proteolysis \\
\hline $\begin{array}{l}\text { Ubiquitin carboxyl-terminal hydrolase } \\
\text { isozyme L1 }\end{array}$ & Uchl1 & Q00981 & $\uparrow \downarrow$ & Cytoplasm & $\begin{array}{l}\text { Proteolysis, regulation of cell morphology (e.g. } \\
\text { dendritic arborization), signal transduction }\end{array}$ \\
\hline \multicolumn{6}{|l|}{ Response to oxidative stress } \\
\hline Glutathione S-transferase Mu 1 & Gstm1 & P04905 & $\downarrow$ & Cytoplasm & Response to oxidative stress \\
\hline Glutathione S-transferase P & Gstp1 & P04906 & $\uparrow$ & Cytoplasm & Response to oxidative stress \\
\hline Peroxiredoxin-1 & Prdx1 & Q63716 & $\uparrow$ & Cytoplasm & Response to oxidative stress \\
\hline Peroxiredoxin-2 & $\operatorname{Prdx} 2$ & P35704 & $\uparrow \downarrow$ & Cytoplasm & Response to oxidative stress \\
\hline $\begin{array}{l}\text { Thioredoxin-dependent peroxide reductase, } \\
\text { mitochondrial }\end{array}$ & Prdx3 & P20108 & $\uparrow$ & Cytoplasm & Response to oxidative stress \\
\hline Peroxiredoxin-5, mitochondrial & $\operatorname{Prdx} 5$ & Q9R063 & $\uparrow \uparrow$ & Cytoplasm & Response to oxidative stress \\
\hline Peroxiredoxin-6 & Prdx6 & 035244 & $\downarrow$ & Cytoplasm & Response to oxidative stress \\
\hline Superoxide dismutase [Mn], mitochondrial & Sod2 & P07895 & $\uparrow$ & Mitochondrion & Response to oxidative stress \\
\hline Thioredoxin & Txn & P11232 & $\uparrow$ & Cytoplasm & Response to oxidative stress \\
\hline \multicolumn{6}{|l|}{ Cytoskeletal protein } \\
\hline Actin, cytoplasmic 1 & Actb & P60711 & $\uparrow \uparrow \uparrow \downarrow$ & Cytoplasm & Microfilamental component \\
\hline Beta-centractin & Actr1b & Q8R5C5 & $\downarrow$ & Cytoplasm & Vesicle trafficking \\
\hline Actin-related protein $2 / 3$ complex subunit 5 & Arpc5 & Q4KLF8 & $\downarrow$ & Cytoplasm & Regulation of actin cytoskeleton \\
\hline F-actin-capping protein subunit alpha-2 & Capza2 & Q3T1K5 & $\downarrow$ & Cytoplasm & Microfilament organization \\
\hline F-actin-capping protein subunit beta & Capzb & Q5XI32 & $\downarrow$ & Cytoplasm & Microfilament organization, synaptic remodelling \\
\hline Cofilin-1 & Cfl1 & P45592 & $\uparrow \uparrow \downarrow$ & Cytoplasm & $\begin{array}{l}\text { Regulation of microfilaments, synaptogenesis, } \\
\text { neurotransmitter receptor localization }\end{array}$ \\
\hline Cofilin-2 & Cfl2 & P45591 & $\uparrow$ & Cytoplasm & $\begin{array}{l}\text { Regulation of microfilaments, synaptogenesis, } \\
\text { neurotransmitter receptor localization }\end{array}$ \\
\hline Protein canopy homolog 2 & Cnpy2 & Q9QXT0 & $\downarrow$ & $\begin{array}{l}\text { Endoplasmic reticulum, } \\
\text { cytoplasm }\end{array}$ & Neurite outgrowth \\
\hline Dihydropyrimidinase-related protein 5 & Dpysl5 & Q9JHU0 & $\downarrow$ & Cytoplasm & $\begin{array}{l}\text { Neurite outgrowth, regulation of dendritic } \\
\text { arborization }\end{array}$ \\
\hline Glial fibrillary acidic protein & Gfap & P47819 & $\downarrow$ & Cytoplasm & Intermediate filament organization \\
\hline Alpha-internexin & Ina & P23565 & $\uparrow \uparrow \uparrow$ & Cytoplasm & $\begin{array}{l}\text { Microfilament organization, neurite outgrowth, } \\
\text { regulation of dendrite morphology }\end{array}$ \\
\hline Myelin basic protein $\mathrm{S}$ & Mbp & P02688 & $\uparrow \uparrow \downarrow \downarrow$ & Cytoplasm & Regulation of microfilaments and microtubules \\
\hline Stathmin & Stmn1 & P13668 & $\uparrow$ & Cytoplasm & Regulation of microtubules, synaptogenezis \\
\hline Tubulin alpha- $1 C$ chain & Tuba1c & Q6AYZ1 & $\downarrow$ & Cytoplasm & Microtubular component \\
\hline \multicolumn{6}{|l|}{ Signal transduction } \\
\hline $\begin{array}{l}\text { Guanine nucleotide-binding protein } \mathrm{G}(\mathrm{o}) \\
\text { subunit alpha }\end{array}$ & Gnao1 & P59215 & $\downarrow$ & Cytoplasm & Signal transduction, neurite outgrowth \\
\hline $\begin{array}{l}\text { Guanine nucleotide-binding protein } \\
G(I) / G(S) / G(T) \text { subunit beta-1 }\end{array}$ & Gnb1 & P54311 & $\uparrow \uparrow$ & Cytoplasm & Signal transduction \\
\hline Growth factor receptor-bound protein 2 & Grb2 & P62994 & $\uparrow$ & Cytoplasm & Signal transduction, synaptic vesicle recycling \\
\hline $\begin{array}{l}\text { Phosphatidylethanolamine-binding protein } \\
1\end{array}$ & Pebp1 & P31044 & $\uparrow \downarrow$ & Cytoplasm & Signal transduction \\
\hline 14-3-3 protein epsilon & Ywhae & P62260 & $\uparrow$ & Cytoplasm & Signal transduction \\
\hline 14-3-3 protein zeta/delta & Ywhaz & P63102 & $\downarrow$ & Cytoplasm & Signal transduction \\
\hline \multicolumn{6}{|l|}{ Miscellaneous } \\
\hline Annexin A4 & Anxa4 & P55260 & $\downarrow$ & Cytoplasm, nucleus & Signal transduction, synaptic vesicle exocytosis \\
\hline Alcohol dehydrogenase [NADP +] & Akr1a1 & P51635 & $\downarrow \downarrow$ & Cytoplasm & Alcohol and aldehyde metabolism \\
\hline Flavin reductase & Blvrb & Q923D2 & $\uparrow$ & Cytoplasm & Flavin and biliverdin metabolism \\
\hline $\begin{array}{r}\mathrm{N}(\mathrm{G}), \mathrm{N}(\mathrm{G}) \text {-dimethylarginine } \\
\text { dimethylaminohydrolase } 2\end{array}$ & Ddah2 & Q6MG60 & $\downarrow$ & Cytoplasm & Regulation of nitric oxide synthesis \\
\hline 3-Hydroxyacyl-CoA dehydrogenase type-2 & Hsd17b10 & 070351 & $\downarrow$ & Mitochondrion & Steroid metabolism \\
\hline Latexin & Lxn & Q64361 & $\downarrow$ & Cytoplasm & Unknown \\
\hline Protein NDRG2 & Ndrg2 & Q8VBU2 & $\uparrow$ & Cytoplasm & $\begin{array}{l}\text { Synaptogenesis, regulation of neurite } \\
\text { outgrowth, signal transduction }\end{array}$ \\
\hline Nucleoside diphosphate kinase B & Nme2 & P19804 & $\downarrow$ & Cytoplasm & $\begin{array}{l}\text { Neurite outgrowth, cell differentiation, signal } \\
\text { transduction, synaptic vesicle endocytosis }\end{array}$ \\
\hline Pyridoxal kinase & Pdxk & 035331 & $\downarrow$ & Cytoplasm & Pyridoxal metabolism \\
\hline Ran-specific GTPase-activating protein & Ranbp1 & P34022 & $\downarrow$ & Cytoplasm, nucleus & Nuclear transport \\
\hline Translationally-controlled tumor protein & Tpt1 & P63029 & $\uparrow$ & Cytoplasm & $\begin{array}{l}\text { Regulation of microtubular and microfilamental } \\
\text { organization and calcium homeostasis }\end{array}$ \\
\hline Transitional endoplasmic reticulum ATPase & Vcp & P46462 & $\uparrow$ & $\begin{array}{l}\text { Endoplasmic reticulum, } \\
\text { cytoplasm }\end{array}$ & $\begin{array}{l}\text { Vesicle trafficking and fusion, regulation of } \\
\text { proteolysis }\end{array}$ \\
\hline UPF0568 protein C14orf166 homolog & - & Q9CQE8 & $\uparrow$ & Unknown & Unknown \\
\hline ES1 protein homolog, mitochondrial & - & P56571 & $\downarrow \downarrow$ & Mitochondrion & Unknown \\
\hline
\end{tabular}

\footnotetext{
a Directions of alterations in the levels of the corresponding protein spots (due to expression changes or post-translational modifications).
} 
Table 4

List of significantly altered RS synaptic proteins from the thalamus, assigned to functional groups.

\begin{tabular}{|c|c|c|c|c|c|}
\hline Protein name & $\begin{array}{l}\text { Gene } \\
\text { name }\end{array}$ & $\begin{array}{l}\text { Accession } \\
\text { number }\end{array}$ & $\begin{array}{l}\text { Up/down } \\
\text { regulation }^{\mathrm{a}}\end{array}$ & Cellular localization & Cellular function \\
\hline \multicolumn{6}{|l|}{ Carbohydrate and energy metabolism } \\
\hline Aconitate hydratase, mitochondrial & Aco2 & Q9ER34 & $\downarrow \downarrow \downarrow \downarrow \downarrow$ & Mitochondrion & Tricarboxylic acid cycle \\
\hline Fructose-bisphosphate aldolase A & Aldoa & P05065 & $\uparrow$ & Cytoplasm & Glycolysis \\
\hline Alpha-enolase & Eno1 & P04764 & $\downarrow \downarrow$ & Cytoplasm & Glycolysis \\
\hline $\begin{array}{c}\text { Fumarylacetoacetate hydrolase } \\
\text { domain-containing protein } 2\end{array}$ & Fahd2 & B2RYW9 & $\downarrow$ & Mitochondrion & Carbohydrate and amino acid metabolism \\
\hline Glyceraldehyde-3-phosphate dehydrogenase & Gapdh & P04797 & $\downarrow$ & Cytoplasm & Glycolysis \\
\hline $\begin{array}{l}\text { Succinyl-CoA:3-ketoacid-coenzyme A } \\
\text { transferase } 1 \text {, mitochondrial }\end{array}$ & Oxct1 & B2GV06 & $\downarrow$ & Mitochondrion & Metabolism of ketone bodies \\
\hline Phosphoglycerate mutase 1 & Pgam1 & P25113 & $\downarrow$ & Cytoplasm & Carbohydrate metabolism, glycolysis \\
\hline \multicolumn{6}{|l|}{ Amino acid metabolism } \\
\hline Cytosol aminopeptidase & Lap3 & Q68FS4 & $\downarrow$ & Cytoplasm & Protein and peptide metabolism \\
\hline \multicolumn{6}{|l|}{ Lipid metabolism } \\
\hline Enoyl-CoA hydratase, mitochondrial & Echs1 & P14604 & $\downarrow$ & Mitochondrion & Fatty acid metabolism \\
\hline \multicolumn{6}{|l|}{ Synaptic transmission } \\
\hline V-type proton ATPase catalytic subunit A & Atp6v1a & P50516 & $\downarrow$ & $\begin{array}{l}\text { Cytoplasm, membrane of intracellular } \\
\text { compartments, mitochondrion }\end{array}$ & $\begin{array}{l}\text { Neurotransmitter uptake into synaptic vesicles, } \\
\text { pH regulation in intracellular compartments }\end{array}$ \\
\hline Dihydropyrimidinase-related protein 2 & Dpysl2 & P47942 & $\uparrow \downarrow$ & Cytoplasm & $\begin{array}{l}\text { Neurite outgrowth, synaptic vesicle exocytosis, } \\
\text { receptor recycling }\end{array}$ \\
\hline Gamma-soluble NSF attachment protein & Napg & Q9CWZ7 & $\downarrow$ & Cytoplasm & Vesicular transport, synaptic vesicle exocytosis \\
\hline Septin-5 & Sept5 & Q9JJM9 & $\uparrow \downarrow$ & Cytoplasm & Synaptic vesicle exocytosis, neurite outgrowth \\
\hline \multicolumn{6}{|l|}{ Protein synthesis and folding } \\
\hline T-complex protein 1 subunit beta & Cct2 & Q5XIM9 & $\uparrow$ & Cytoplasm & Protein (e.g. actin and tubulin) folding \\
\hline Heat shock cognate 71 kDa protein & Hspa8 & P63018 & $\downarrow \downarrow$ & Cytoplasm & Protein folding, macromolecular assembly \\
\hline Heat shock protein beta- 8 & Hspb8 & Q9EPX0 & $\uparrow$ & Cytoplasm & Chaperone function \\
\hline Stress-induced-phosphoprotein 1 & Stip1 & 035814 & $\uparrow$ & Cytoplasm & Chaperone function \\
\hline \multicolumn{6}{|l|}{ Proteolysis } \\
\hline COP9 signalosome complex subunit 4 & Cops4 & Q68FS2 & $\uparrow$ & Cytoplasm, nucleus & $\begin{array}{l}\text { Regulation of protein degradation, modulation } \\
\text { of the dendritic arborization }\end{array}$ \\
\hline Cathepsin D & Ctsd & P24268 & $\uparrow$ & Cytoplasm & $\begin{array}{l}\text { Lysosomal protein degradation, synaptic } \\
\text { transmission }\end{array}$ \\
\hline \multicolumn{6}{|l|}{ Response to oxidative stress } \\
\hline Peroxiredoxin-2 & $\operatorname{Prdx} 2$ & P35704 & $\downarrow$ & Cytoplasm & Response to oxidative stress \\
\hline Peroxiredoxin-6 & $\operatorname{Prdx} 6$ & O35244 & $\uparrow \downarrow$ & Cytoplasm & Response to oxidative stress \\
\hline \multicolumn{6}{|l|}{ Cytoskeletal protein } \\
\hline Dihydropyrimidinase-related protein 3 & Dpysl3 & Q62952 & $\uparrow$ & Cytoplasm & $\begin{array}{l}\text { Regulation of the actin cytoskeleton and neurite } \\
\text { outgrowth }\end{array}$ \\
\hline Glial fibrillary acidic protein & Gfap & P47819 & $\downarrow$ & Cytoplasm & Intermediate filament organization \\
\hline \multicolumn{6}{|l|}{ Signal transduction } \\
\hline Dual specificity protein phosphatase 3 & Dusp3 & Q9D7X3 & $\downarrow$ & Nucleus & Signal transduction, ERK dephosphorylation \\
\hline $\begin{array}{l}\text { Guanine nucleotide-binding protein } \\
\mathrm{G}(\mathrm{I}) / \mathrm{G}(\mathrm{S}) / \mathrm{G}(\mathrm{T}) \text { subunit beta-1 }\end{array}$ & Gnb1 & P54311 & $\downarrow$ & Cytoplasm & Signal transduction \\
\hline Phosphatidylethanolamine-binding protein 1 & Pebp1 & P31044 & $\downarrow$ & Cytoplasm & Signal transduction \\
\hline \multicolumn{6}{|l|}{ Miscellaneous } \\
\hline STIP1 homology and U box-containing protein 1 & Stub1 & Q9WUD1 & $\downarrow$ & Cytoplasm & $\begin{array}{l}\text { Modulation of chaperone proteins, } \\
\text { ubiquitination }\end{array}$ \\
\hline $\begin{array}{l}\text { Voltage-dependent anion-selective channel } \\
\text { protein } 2\end{array}$ & Vdac2 & P81155 & $\uparrow$ & Mitochondrion & Modulation of intracellular calcium levels \\
\hline
\end{tabular}

a Directions of alterations in the levels of the corresponding protein spots (due to expression changes or post-translational modifications).

molecules in processes leading to altered synaptic transmission - as described in the case of nitric oxide or superoxide (Böhme et al., 1993; Knapp and Klann, 2002).

There is a hypothesis of sleep function presuming that macromolecule synthesis is generally enhanced in sleep to restore the decreased levels of macromolecules in waking (Mackiewicz et al., 2007; Ramm and Smith, 1990). The majority of protein synthesis- and folding related-proteins showed increased levels in the parietal cortex of SD group $(n=7)$ (Table 1), but in the thalamus, most of the proteins categorized in this group showed opposite direction changes in $\operatorname{SD}(n=6)$ (Table 2). The long-term effects of sleep deprivation (RS group) caused bidirectional changes in protein synthesis-related proteins. We have also identified a set of proteins possessing chaperone function necessary for the proper folding of the newly synthesized proteins, and notably, for the proper construction of macromolecular assemblies. These proteins might be associated with the restorative function of sleep (Tables 1-4).

\subsection{The role of SD and $R S$ protein changes related to synaptic plasticity}

Since one of our main aims was to ask whether the uncovered proteomic changes support the synaptic homeostasis hypothesis (Tononi and Cirelli, 2014), we are discussing that issue. The hypothesis is based on the assumption that the net synaptic strength increases in waking and, in turn, in sleep deprivation, while decreases in sleep. In other words, it claims that waking saturates synaptic plasticity, which 
A

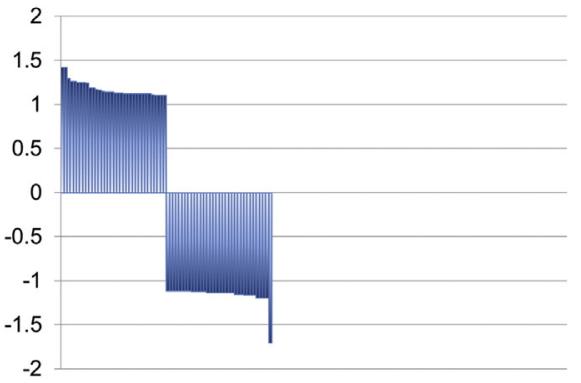

C

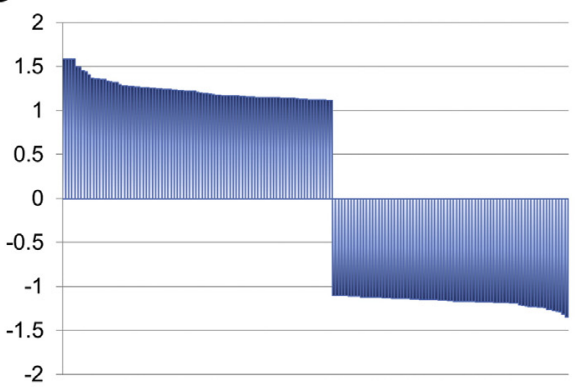

B

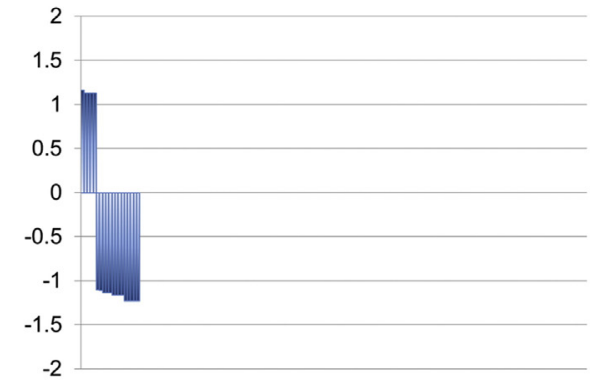

D

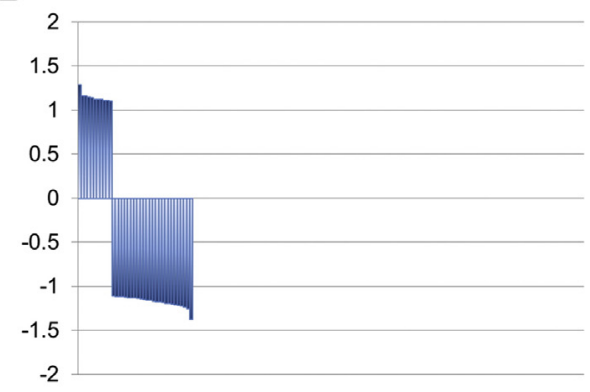

\section{E}
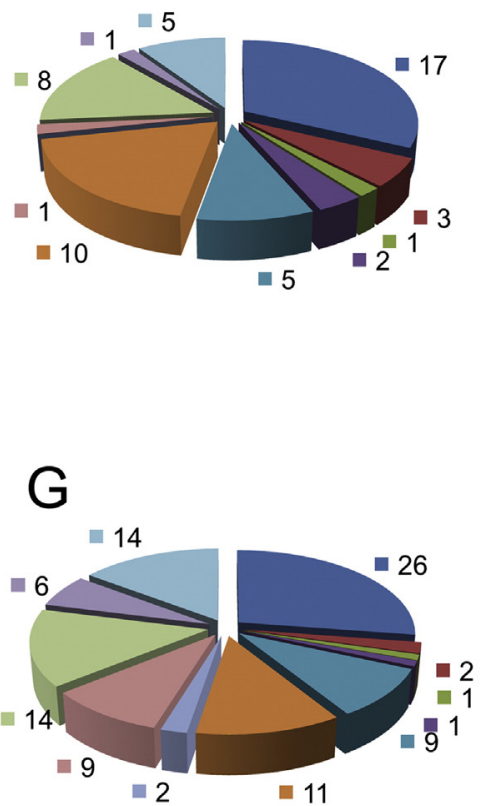

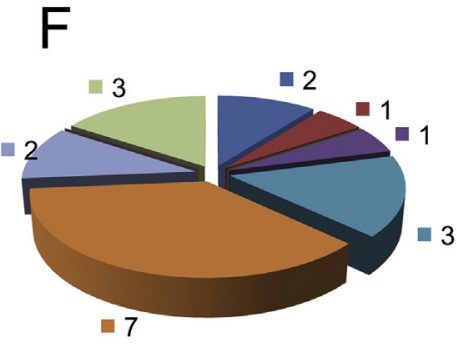

$\mathrm{H}$

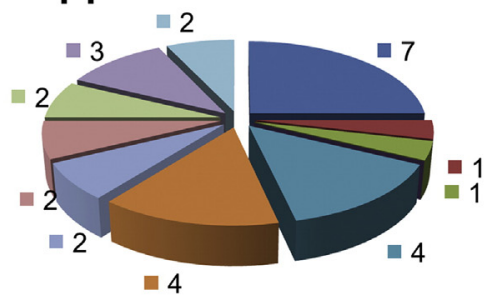

- Carbohydrate and energy metabolism - Amino acid metabolism

- Lipid metabolism

- Nucleotide metabolism

- Synaptic transmission

- Protein synthesis and folding

Proteolysis

Response to oxidative stress

Cytoskeletal

- Signal transduction

Miscellaneous

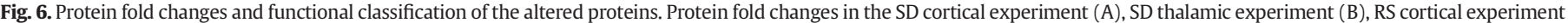
(C), and RS thalamic experiment (D). Functional classification of SD cortical proteins (E), SD thalamic proteins (F), RS cortical proteins (G) and RS thalamic proteins (H).

is desaturated in sleep. The saturation of synaptic plasticity may weakens learning ability, thus synapses became rigid, which can explain the sleep deprivation-induced impairments in memory consolidation (Stickgold, 2005). The theoretical speculation on synaptic reorganization in sleep and waking predicts that synapses are extensively rebuilt during the sleep-wake cycle depending mostly on the duration of waking and the experiences received during it.

Our proteomics study uncovered that a large group of altered proteins are linked directly to synaptic strength regulation and plasticity via their influence on e.g., synaptic vesicle recycling and synaptogenesis (Fig. 8). All of these proteins participate in various aspects of plasticity in the synaptic machinery. The highest number of synaptic plasticity-related proteins were affected by the long-term influence of sleep deprivation (RS group) in the parietal cortex (Fig. 8). This data points out also that synaptic reorganization is not only apparent $16 \mathrm{~h}$ after an $8 \mathrm{~h}$ long sleep deprivation, but even more widespread at this time than immediately after the deprivation procedure. Therefore, extensive molecular alterations, predicted by the synaptic homeostasis hypothesis, can be verified. 
A

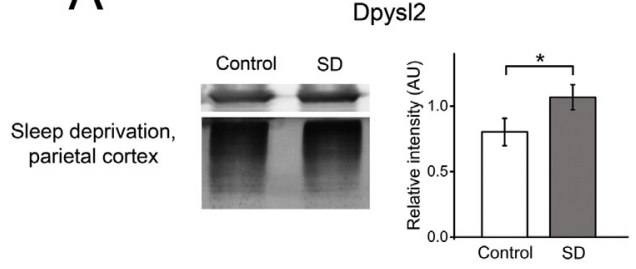

B

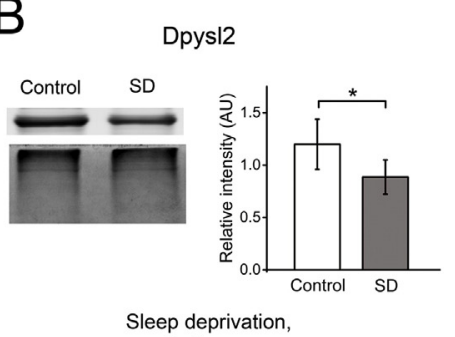
thalamus
Anxa3

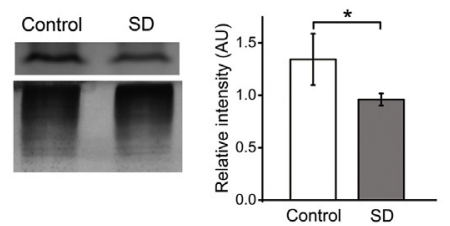

C

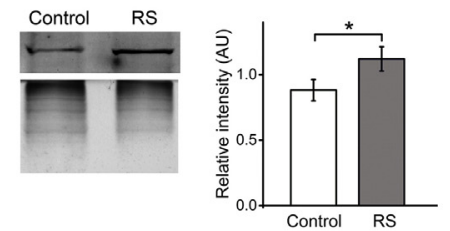

Recovery sleep,

parietal cortex
Hspa8
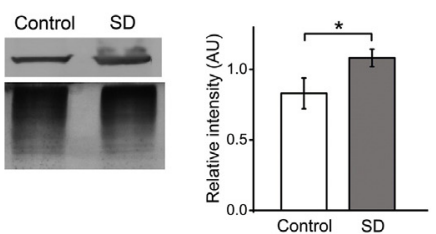

Hspa8
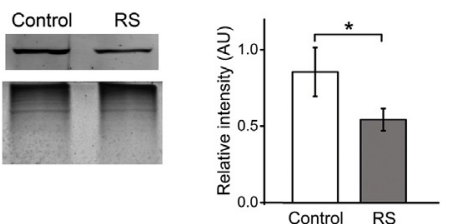

Recovery sleep, thalamus

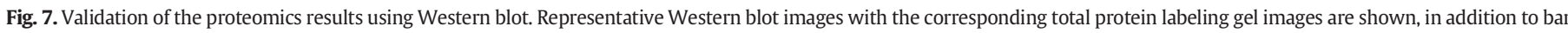

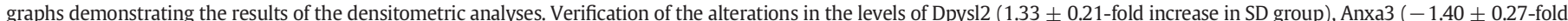

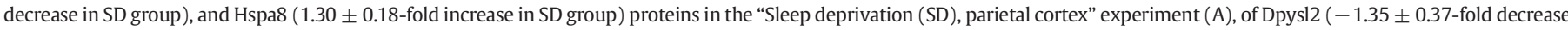

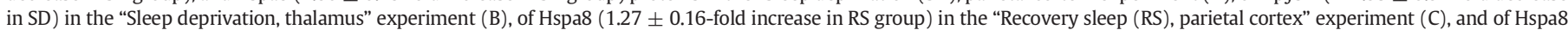
$(-1.57 \pm 0.36$-fold decrease in RS group $)$ in the "Recovery sleep, thalamus" experiment. Means \pm S.E.M. are presented; $n=6$ per experimental group; ${ }^{*} p<0.05$.

\section{Conclusions}

Subcellular enrichment technique for the investigation of synaptic protein level alterations induced by the short- and long-term effects of sleep deprivation revealed that the synaptic molecular machinery is extensively impaired. Our results suggest that sleep has a very complex role at the synaptic level, such as the restorative, homeostatic, and plasticity-enhancing functions that is reflected by the detectable changes in synaptic proteome. Therefore, sophisticated alterations of the synaptic protein machinery during sleep are possible which could improve its printability (plasticity) and enhance its stability at the same time. We revealed that sleep deprivation more extensively influences the parietal cortex than the thalamus, and its long-term effects on the molecular level are remarkable - might be due to the recovery sleep period. The most important conclusion is that the revealed widespread synaptic proteome changes support the synaptic homeostasis hypothesis of sleep.

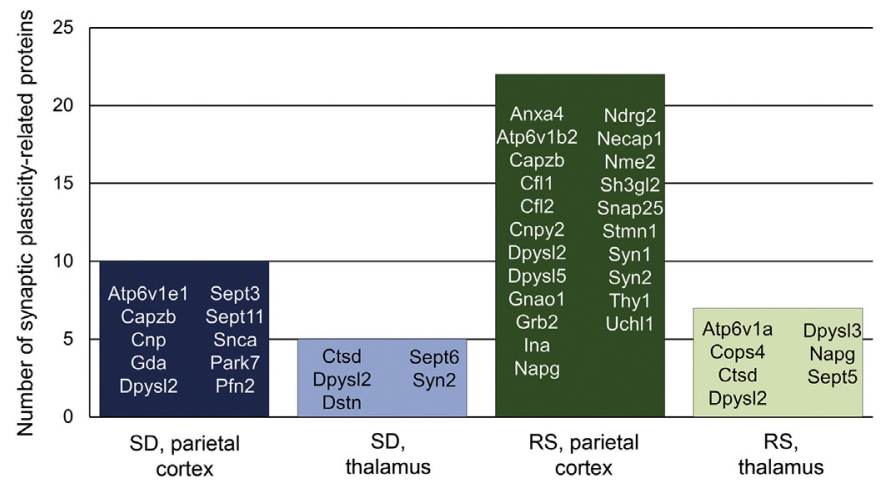

Fig. 8. The list of altered synaptic plasticity-related proteins. We revealed 10, 5, 22 and 7 altered proteins in the SD parietal cortex, SD thalamus, RS parietal cortex and RS thalamus, respectively, which are implicated in the regulation of the plasticity of synaptic transmission.
Supplementary data to this article can be found online at http://dx. doi.org/10.1016/j.mcn.2017.01.002.

\section{Conflict of interest statement}

All authors declare that there are no conflicts of interest.

\section{Acknowledgements}

This work was supported by the National Development Agency of Hungary TÁMOP 4.2.1./B-09/1/KMR-2010-0003 (Gábor Juhász and Katalin Adrienna Kékesi), the KTIA NAP_13-2-2014-0004 (Katalin Völgyi), the KTIA_NAP_13-2-2015-0003 (Gábor Juhász, László Drahos, Vilmos Tóth, and Péter Gulyássy), the KTIA_NAP_13-2-2014-0017 (Balázs András Györffy) and the KTIA_NAP_13-2-2014-0002 (Zsolt Borhegyi).

\section{References}

Abraham, W.C., Otani, S., 1991. Macromolecules and the maintenance of long-term potentiation. In: Morrell, F. (Ed.), Kindling and Synaptic Plasticity. The legacy of Graham Goddard, Birkhausen, pp. 92-109.

Abramoff, M.D., Magalhaes, P.J., Ram, S.J., 2004. Image processing with ImageJ. Biophoton. Int. 11, 36-42.

Bajor, M., Michaluk, P., Gulyássy, P., Kékesi, A.K., Juhász, G., Kaczmarek, L., 2012. Synaptic cell adhesion molecule-2 and collapsin response mediator protein-2 are novel members of the matrix metalloproteinase-9 degradome. J. Neurochem. 122, 775-788.

Baker, E.K., Richdale, A.L., 2015. Sleep patterns in adults with a diagnosis of high-functioning autism spectrum disorder. Sleep 38, 1765-1774.

Basheer, R., Brown, R., Ramesh, V., Begum, S., McCarley, R.W., 2005. Sleep deprivation-induced protein changes in basal forebrain: implications for synaptic plasticity. J. Neurosci. Res. 82, 650-658.

Benington, J.H., Frank, M.G., 2003. Cellular and molecular connections between sleep and synaptic plasticity. Prog. Neurobiol. 69, 71-101.

Benington, J.H., Heller, H.C., 1995. Restoration of brain energy metabolism as the function of sleep. Prog. Neurobiol. 45, 347-360.

Blanco, W., Pereira, C.M., Cota, V.R., Souza, A.C., Rennó-Costa, C., Santos, S., Dias, G., Guerreiro, A.M., Tort, A.B., Neto, A.D., Ribeiro, S., 2015. Synaptic homeostasis and restructuring across the sleep-wake cycle. PLoS Comput. Biol. 11, e1004241.

Blissitt, P.A., 2001. Sleep, memory, and learning. J. Neurosurg. Nurs. 33, 208-215.

Bloch, V., Hennevin, E., Leconte, P., 1977. Interaction between post-trial reticular stimulation and subsequent paradoxical sleep in memory consolidation processes. In: 
Drucker-Colin, M.J. (Ed.), Neurobiology of Sleep and Memory. Academic Press, New York, pp. 255-272.

Bloch, V., Hennevin, E., Leconte, P., 1979. Relationship between paradoxical sleep and memory processes. In: Razier, M. (Ed.), Brain Mechanisms in Memory and Learning: From the Single Neuron to Man. Raven Press, New York, pp. 329-343.

Böhme, G.A., Bon, C., Lemaire, M., Reibaud, M., Piot, O., Stutzmann, J.M., Doble, A., Blanchard, J.C., 1993. Altered synaptic plasticity and memory formation in nitric oxide synthase inhibitor-treated rats. Proc. Natl. Acad. Sci. U. S. A. 90, 9191-9194.

Braun, A.R., Balkin, T.J., Wesenten, N.J., Carson, R.E., Varga, M., Baldwin, P., Selbie, S., Belenky, G., Herscovitch, P., 1997. Regional cerebral blood flow throughout the sleep-wake cycle. An H2(15)O PET study. Brain 120, 1173-1197.

Brown, M.K., Naidoo, N., 2010. The UPR and the anti-oxidant response: relevance to sleep and sleep loss. Mol. Neurobiol. 42, 103-113.

Bushey, D., Tononi, G., Cirelli, C., 2011. Sleep and synaptic homeostasis: structural evidence in Drosophila. Science 332, 1576-1581.

Chee, M.W., Choo, W.C., 2004. Functional imaging of working memory after $24 \mathrm{hr}$ of tota sleep deprivation. J. Neurosci. 24, 4560-4567.

Chee, M.W., Chuah, L.Y., Venkatraman, V., Chan, W.Y., Philip, P., Dinges, D.F., 2006. Functional imaging of working memory following normal sleep and after 24 and $35 \mathrm{~h}$ of sleep deprivation: correlations of fronto-parietal activation with performance. NeuroImage 31, 419-428.

Chevalier, F., 2010. Highlights on the capacities of "gel-based" proteomics. Proteome Sci. 8,23

Chow, H.M., Horovitz, S.G., Carr, W.S., Picchioni, D., Coddington, N., Fukunaga, M., Xu, Y. Balkin, T.J., Duyn, J.H., Braun, A.R., 2013. Rhythmic alternating patterns of brain activity distinguish rapid eye movement sleep from other states of consciousness. Proc. Natl. Acad. Sci. U. S. A. 110, 10300-10305.

Cirelli, C., Tononi, G., 1998. Differences in gene expression between sleep and waking as revealed by mRNA differential display. Brain Res. Mol. Brain Res. 56, 293-305.

Cirelli, C., Faraguna, U., Tononi, G., 2006. Changes in brain gene expression after long-term sleep deprivation. J. Neurochem. 98, 1632-1645.

Costa-Miserachs, D., Portell-Cortés, I., Torras-Garcia, M., Morgado-Bernal, I., 2003. Automated sleep staging in rat with a standard spreadsheet. J. Neurosci. Methods 130, 93-101.

Dang-Vu, T.T., Desseilles, M., Peigneux, P., Maquet, P., 2006. A role for sleep in brain plasticity. Pediatr. Rehabil. 9, 98-118.

Donnet, A., Farnarier, G., Gambarelli, D., Aguglia, U., Regis, H., 1992. Sleep electroencephalogram at the early stage of Creutzfeldt-Jakob disease. Clin. Electroencephalogr. 23 $118-125$.

Dworak, M., McCarley, R.W., Kim, T., Kalinchuk, A.V., Basheer, R., 2010. Sleep and brain energy levels: ATP changes during sleep. J. Neurosci. 30, 9007-9016.

Eaton, S.L., Roche, S.L., Llavero Hurtado, M., Oldknow, K.J., Farquharson, C., Gillingwater, T.H., Wishart, T.M., 2013. Total protein analysis as a reliable loading control for quantitative fluorescent Western blotting. PLoS One 8, e72457.

Fenzl, T., Romanowski, C.P., Flachskamm, C., Honsberg, K., Boll, E., Hoehne, A., Kimura, M. 2007. Fully automated sleep deprivation in mice as a tool in sleep research. J. Neurosci. Methods 166, 229-235.

Giedke, H., Schwärzler, F., 2002. Therapeutic use of sleep deprivation in depression. Sleep Med. Rev. 6, 361-377.

Goel, N., Rao, H., Durmer, J.S., Dinges, D.F., 2005. Neurocognitive consequences of sleep deprivation. Semin. Neurol. 25, 117-129.

Huang, E.P., 1998. Synaptic plasticity: going through phases with LTP. Curr. Biol. 8, R350-R352.

Ikeda, M., Ikeda-Sagara, M., Okada, T., Clement, P., Urade, Y., Nagai, T., Sugiyama, T., Yoshioka, T., Honda, K., Inoué, S., 2005. Brain oxidation is an initial process in sleep induction. Neuroscience 130, 1029-1040.

Ishikawa, A., Kanayama, Y., Matsumura, H., Tsuchimochi, H., Ishida, Y., Nakamura, S., 2006. Selective rapid eye movement sleep deprivation impairs the maintenance of longterm potentiation in the rat hippocampus. Eur. J. Neurosci. 24, 243-248.

Jones, S., Pfister-Genskow, M., Benca, R.M., Cirelli, C., 2008. Molecular correlates of sleep and wakefulness in the brain of the white-crowned sparrow. J. Neurochem. 105, 46-62.

Kasai, H., Fukuda, M., Watanabe, S., Hayashi-Takagi, A., Noguchi, J., 2010. Structural dynamics of dendritic spines in memory and cognition. Trends Neurosci. 33, 121-129.

Klann, E., Sweatt, J.D., 2008. Altered protein synthesis is a trigger for long-term memory formation. Neurobiol. Learn. Mem. 89, 247-259.

Knapp, L.T., Klann, E., 2002. Potentiation of hippocampal synaptic transmission by superoxide requires the oxidative activation of protein kinase C. J. Neurosci. 22, 674-683.

Ledoux, L., Sastre, J.P., Buda, C., Luppi, P.H., Jouvet, M., 1996. Alterations in c-fos expression after different experimental procedures of sleep deprivation in the cat. Brain Res. 735, $108-118$.

Lei, Y., Shao, Y., Wang, L., Zhai, T., Zou, F., Ye, E., Jin, X., Li, W., Qi, J., Yang, Z., 2015. Largescale brain network coupling predicts total sleep deprivation effects on cognitive capacity. PLoS One 10, e0133959.

Mackiewicz, M., Shockley, K.R., Romer, M.A., Galante, R.J., Zimmerman, J.E., Naidoo, N., Baldwin, D.A., Jensen, S.T., Churchill, G.A., Pack, A.I., 2007. Macromolecule biosynthesis: a key function of sleep. Physiol. Genomics 31, 441-457.

Madsen, P.L., Schmidt, J.F., Wildschiødtz, G., Friberg, L., Holm, S., Vorstrup, S., Lassen, N.A. 1991. Cerebral $\mathrm{O}_{2}$ metabolism and cerebral blood flow in humans during deep and rapid-eye-movement sleep. J. Appl. Physiol. 70, 2597-2601.

Maquet, P., 1995. Sleep function(s) and cerebral metabolism. Behav. Brain Res. 69, 75-83.

Maret, S., Faraguna, U., Nelson, A.B., Cirelli, C., Tononi, G., 2011. Sleep and waking modulate spine turnover in the adolescent mouse cortex. Nat. Neurosci. 14, 1418-1420.

Martin, K.C., Barad, M., Kandel, E.R., 2000. Local protein synthesis and its role in synapsespecific plasticity. Curr. Opin. Neurobiol. 10, 587-592.
Matsuzaki, M., Honkura, N., Ellis-Davies, G.C., Kasai, H., 2004. Structural basis of long-term potentiation in single dendritic spines. Nature 429, 761-766.

McDermott, C.M., LaHoste, G.J., Chen, C., Musto, A., Bazan, N.G., Magee, J.C., 2003. Sleep deprivation causes behavioral, synaptic, and membrane excitability alterations in hippocampal neurons. J. Neurosci. 23, 9687-9695.

Murphy, M.J., Peterson, M.J., 2015. Sleep disturbances in depression. Sleep Med. Clin. 10, $17-23$.

Nakanishi, H., Sun, Y., Nakamura, R.K., Mori, K., Ito, M., Suda, S., Namba, H., Storch, F.I., Dang, T.P., Mendelson, W., Mishkin, M., Kennedy, C., Gillin, J.C., Smith, C.B., Sokoloff, L., 1997. Positive correlations between cerebral protein synthesis rates and deep sleep in Macaca mulatta. Eur. J. Neurosci. 9, 271-279.

Pawlyk, A.C., Ferber, M., Shah, A., Pack, A.I., Naidoo, N., 2007. Proteomic analysis of the effects and interactions of sleep deprivation and aging in mouse cerebral cortex. J. Neurochem. 103, 2301-2313.

Picchioni, D., Duyn, J.H., Horovitz, S.G., 2013. Sleep and the functional connectome. Neurolmage 80, 387-396.

Pielot, R., Smalla, K.H., Müller, A., Landgraf, P., Lehmann, A.C., Eisenschmidt, E., Haus, U.U., Weismantel, R., Gundelfinger, E.D., Dieterich, D.C., 2012. SynProt: a database for proteins of detergent-resistant synaptic protein preparations. Front Synaptic Neurosci. 4,1

Poirrier, J.E., Guillonneau, F., Renaut, J., Sergeant, K., Luxen, A., Maquet, P., Leprince, P., 2008. Proteomic changes in rat hippocampus and adrenals following short-term sleep deprivation. Proteome Sci. 6, 14.

Ramanathan, L., Siegel, J.M., 2011. Sleep deprivation under sustained hypoxia protects against oxidative stress. Free Radic. Biol. Med. 51, 1842-1848.

Ramanathan, L., Hu, S., Frautschy, S.A., Siegel, J.M., 2010. Short-term total sleep deprivation in the rat increases antioxidant responses in multiple brain regions without impairing spontaneous alternation behavior. Behav. Brain Res. 207, 305-309.

Ramm, P., Smith, C.T., 1990. Rates of cerebral protein synthesis are linked to slow wave sleep in the rat. Physiol. Behav. 48, 749-753.

Rechtschaffen, A., Bergmann, B.M., Gilliland, M.A., Bauer, K., 1999. Effects of method, duration, and sleep stage on rebounds from sleep deprivation in the rat. Sleep 22, 11-31.

Reimund, E., 1994. The free radical flux theory of sleep. Med. Hypotheses 43, 231-233.

Reynolds 3rd, C.F., Hoch, C.C., Stack, J., Campbell, D., 1988. The nature and management of sleep/wake disturbance in Alzheimer's dementia. Psychopharmacol. Bull. 24, 43-48.

Rumpel, S., LeDoux, J., Zador, A., Malinow, R., 2005. Postsynaptic receptor trafficking underlying a form of associative learning. Science 308, 83-88.

Short, M.A., Louca, M., 2015. Sleep deprivation leads to mood deficits in healthy adolescents. Sleep Med. 16, 987-993.

Starkstein, S.E., Preziosi, T.J., Robinson, R.G., 1991. Sleep disorders, pain, and depression in Parkinson's disease. Eur. Neurol. 31, 352-355.

Steriade, M., 2006. Grouping of brain rhythms in corticothalamic systems. Neuroscience 137, 1087-1106.

Steriade, M., Llinás, R.R., 1988. The functional states of the thalamus and the associated neuronal interplay. Physiol. Rev. 68, 649-742.

Stickgold, R., 2005. Sleep-dependent memory consolidation. Nature 437, 1272-1278.

Sweatt, J.D., 1999. Toward a molecular explanation for long-term potentiation. Learn. Mem. 6, 399-416.

Szabó, Z., Szeline Szomor, J., Földi, I., Janáky, T., 2012. Mass spectrometry-based label free quantification of gel separated proteins. J. Proteome 75, 5544-5553.

Szegő, E.M., Janáky, T., Szabó, Z., Csorba, A., Kompagne, H., Müller, G., Lévay, G., Simor, A., Juhász, G., Kékesi, K.A., 2010. A mouse model of anxiety molecularly characterized by altered protein networks in the brain proteome. Eur. Neuropsychopharmacol. 20, 96-111.

Terao, A., Greco, M.A., Davis, R.W., Heller, H.C., Kilduff, T.S., 2003a. Region-specific changes in immediate early gene expression in response to sleep deprivation and recovery sleep in the mouse brain. Neuroscience 120,1115-1124.

Terao, A., Steininger, T.L., Hyder, K., Apte-Deshpande, A., Ding, J., Rishipathak, D., Davis, R.W., Heller, H.C., Kilduff, T.S., 2003b. Differential increase in the expression of heat shock protein family members during sleep deprivation and during sleep. Neuroscience 116, 187-200.

Tomasi, D., Wang, R.L., Telang, F., Boronikolas, V., Jayne, M.C., Wang, G.J., Fowler, J.S., Volkow, N.D., 2009. Impairment of attentional networks after 1 night of sleep deprivation. Cereb. Cortex 19, 233-240.

Tominaga-Yoshino, K., Urakubo, T., Okada, M., Matsuda, H., Ogura, A., 2008. Repetitive induction of late-phase LTP produces long-lasting synaptic enhancement accompanied by synaptogenesis in cultured hippocampal slices. Hippocampus 18, 281-293.

Tononi, G., Cirelli, C., 2003. Sleep and synaptic homeostasis: a hypothesis. Brain Res. Bull. $620,143-150$.

Tononi, G., Cirelli, C., 2006. Sleep function and synaptic homeostasis. Sleep Med. Rev. 100, 49-62.

Tononi, G., Cirelli, C., 2014. Sleep and the price of plasticity: from synaptic and cellular homeostasis to memory consolidation and integration. Neuron 81, 12-34.

Trachtenberg, J.T., Chen, B.E., Knott, G.W., Feng, G., Sanes, J.R., Welker, E., Svoboda, K., 2002. Long-term in vivo imaging of experience-dependent synaptic plasticity in adult cortex. Nature 420, 788-794.

Vallee, R.B., Bloom, G.S., 1991. Mechanisms of fast and slow axonal transport. Annu. Rev. Neurosci. 14, 59-92.

Vecsey, C.G., Peixoto, L., Choi, J.H., Wimmer, M., Jaganath, D., Hernandez, P.J., Blackwell, J., Meda, K., Park, A.J., Hannenhalli, S., Abel, T., 2012. Genomic analysis of sleep deprivation reveals translational regulation in the hippocampus. Physiol. Genomics 44, 981-991.

Vitiello, M.V., Prinz, P.N., Williams, D.E., Frommlet, M.S., Ries, R.K., 1990. Sleep disturbances in patients with mild-stage Alzheimer's disease. J. Gerontol. 45, M131-M138. 
Vitiello, M.V., Poceta, J.S., Prinz, P.N., 1991. Sleep in Alzheimer's disease and other dementing disorders. Can. J. Psychol. 45, 221-239.

Vyazovskiy, V.V., Cirelli, C., Tononi, G., Tobler, I., 2008. Cortical metabolic rates as measured by 2-deoxyglucose-uptake are increased after waking and decreased after sleep in mice. Brain Res. Bull. 75, 591-597.

Watson, B.O., Buzsáki, G., 2015. Sleep, memory \& brain rhythms. Daedalus 144, 67-82.

Wiegand, M., Möller, A.A., Schreiber, W., Lauer, C., Krieg, J.C., 1991. Brain morphology and sleep EEG in patients with Huntington's disease. Eur. Arch. Psychiatry Clin. Neurosci. $240,148-152$
Yang, G., Pan, F., Gan, W.B., 2009. Stably maintained dendritic spines are associated with lifelong memories. Nature 462, 920-924.

Yang, G., Lai, C.S., Cichon, J., Ma, L., Li, W., Gan, W.B., 2014. Sleep promotes branch-specific formation of dendritic spines after learning. Science 344, 1173-1178.

Youngblood, B.D., Zhou, J., Smagin, G.N., Ryan, D.H., Harris, R.B., 1997. Sleep deprivation by the "flower pot" technique and spatial reference memory. Physiol. Behav. 61, 249-256. 